\title{
Isolation and characterization of chemical constituents, cytotoxicity, antibacterial and antioxidant activity of the isolates, crude extract from Hornstedtia scyphifera var leaf
}

\author{
Umaru Isaac John ${ }^{1,{ }^{*}}$, Umaru Hauwa A ${ }^{2}$, Yakubu Ojochenemi ${ }^{1}$ and Umaru Kerenhappuch Isaac ${ }^{3}$ \\ ${ }^{1}$ Department of Biochemistry, Federal University Wukari Taraba State. \\ 2 Department of Biochemistry, Modibbo Adama University of Technology Yola Adamawa State. \\ ${ }^{3}$ Department of Biochemistry, University of Maiduguri Borno State.
}

Publication history: Received on 01 February 2020; revised on 06 February 2020; accepted on 12 February 2020

Article DOI: https://doi.org/10.30574/gscbps.2020.10.2.0027

\begin{abstract}
Hornstedtia scyphifera var belongs to ginger family, they are most of time used as spices for cooking, preservatives in food industry and colouring agents. It provides health-promoting effects to cutile certain diseases and ailment such as stomach-ache, Catarrh, asthma, diarrhoea, cold and cough, digestive disorder and rheumatism. In this study, we isolated phytochemicals and investigated the potentials of the leaf crude extract of hexane, dichloromethane, chloroform, ethyl acetate and methanol, cytotoxicity, antioxidant and antibacterial activity. The experiment was performed and two phytochemicals (quercetin and Dodecanoic acid) were isolated and characterised. Significant result was obtained from the isolated compounds and solvent crude extract with hexane and methanol have higher cytotoxicity of 35.462 and 34.059 , chloroform and methanol with higher antioxidant of $34.46 \pm 0.32$ and $35.33 \pm 0.210$. There was an observed significant activity at $500 \mu \mathrm{g} / \mathrm{mL}$ in all the extracts against all the selected pathogen with zone of growth inhibition ranging from $07.70 \pm 27.30 \mathrm{~mm}$ to $27.30 \pm 0.10 \mathrm{~mm}$ in all the solvent extract. The result indicated that with the isolation of quercetin and dodecanoic acid from Hornstedtia scyphifera var Leaf extract is a potential plant medicine which can be harnessed as an agent for antioxidant and potential antibacterial. The compound was isolated for the first time from Hornstedtia scyphifera var.
\end{abstract}

Keywords: Isolation; Characterization; Constituents; Cytotoxicity; Antibacterial; Antioxidant; Hornstedtia scyphifera; GCMS; NMR; FTIR

\section{Introduction}

Numerous efforts by researchers have been directed towards the provision of empirical proof to back the use of tropical plants in traditional medicinal practice. Focus on medicinal plant research has increased worldwide and evidence abounds in the immense potentials of medicinal plants used in various traditional systems (Dahiru et al., 2010).

Various medicinal plants have been studied using different scientific approaches and results from these studies have revealed the potentials of medicinal plants in pharmacology (Fatahi et al., 2003). These medicinal plants such as Hornstedtia scyphifera var are of great importance to the health of the individuals and communities to larger extend, and nutritional benefits are derived from these plants since they are commonly used as vegetables.

Hornstedtia scyphifera var belongs to ginger family, they are most of time used as spices for cooking, preservatives in food industry and colouring agents. However, this species Hornstedtia scyphifera var can provide health-promoting

\footnotetext{
${ }^{*}$ Corresponding author

E-mail address: umaruisaac@gmail.com
} 
effects to cutile certain diseases and ailment such as stomach-ache, Catarrh, asthma, diarrhoea, cold and cough, digestive disorder and rheumatism (Jani et al., 2016).

There are more than ten species, including H. scyphifera, H. ophiuschus and H. phaeochoana found in Sarawak Malaysia (Hashim et al., 2014). The leaf of Hornstedtia scyphifera var leaf was consumed by the Javanese for flavouring, as well as to protect crops from insects by burning them. They are used as an external application to get relief from fever (Holtum, 1950).

The aim of this work is to isolate the phytochemicals and evaluate the potential of the leaves crude extract of its cytotoxicity, antimicrobial and antioxidant.

To the best of our knowledge, there has not been report on any isolated pure compound and bioactivities of this specie Hornstedtia scyphifera var. Here, we are reporting the isolated compound, cytotoxicity, antimicrobial and antioxidant properties of the leaves extracts of Malaysian Hornstedtia scyphifera var.

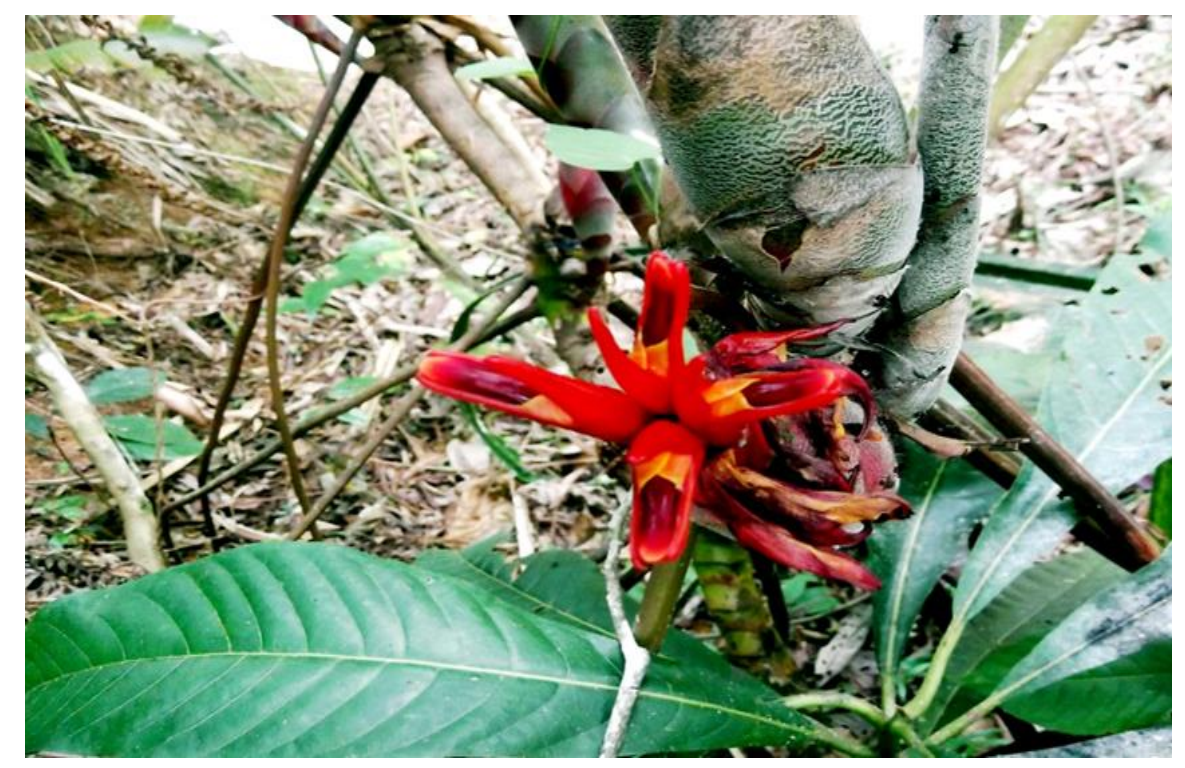

Figure 1 Hornstedtia scyphifera var showing the leaf, flower and stem-bark 

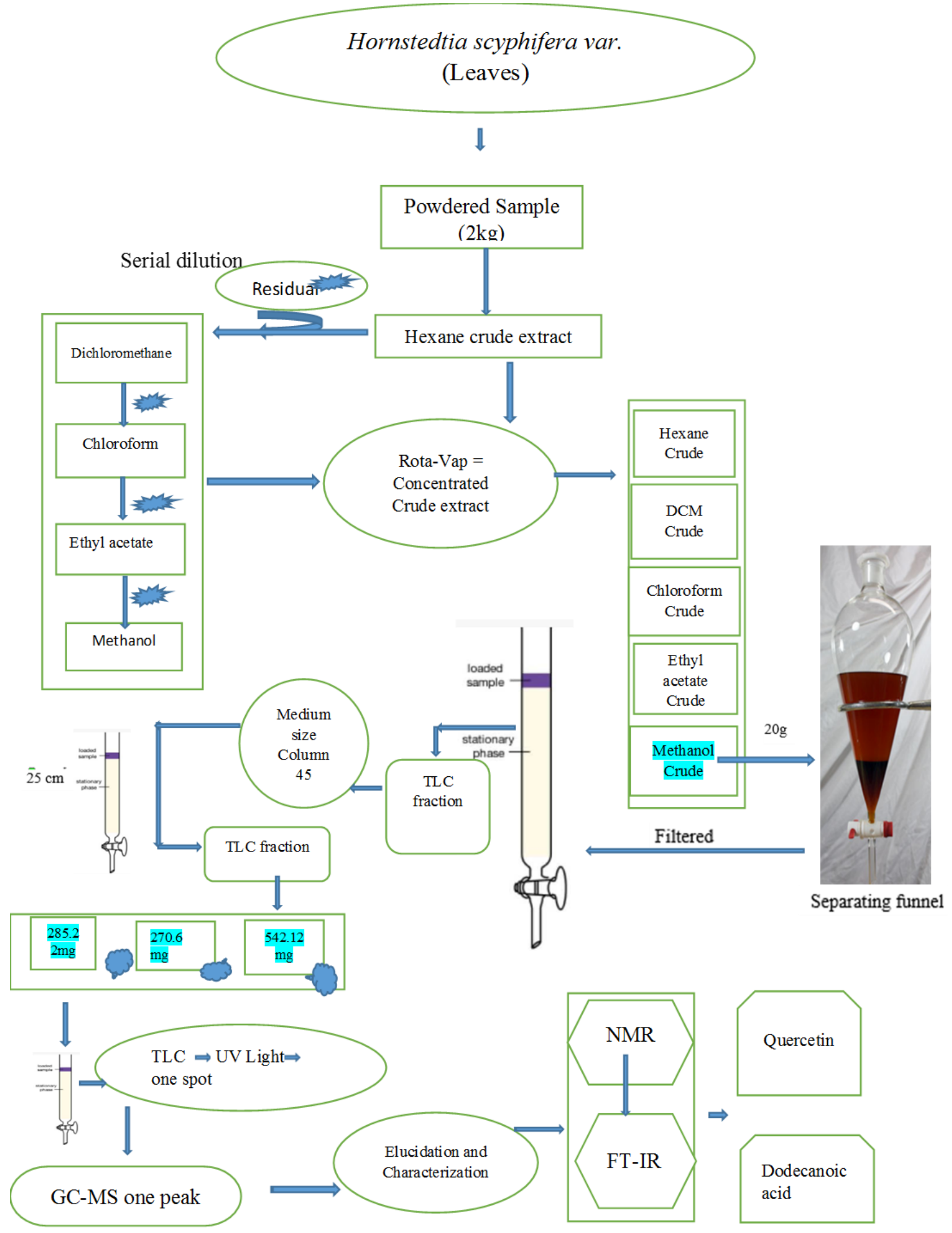

Figure 2 Flow chart for Isolation of pure Compounds 


\section{Material and methods}

\subsection{Plant Material}

\subsubsection{Sample Collection}

The plant material was collected in Singh, Sarawak, Malaysia They were authenticated by a Botanist in the Universiti Malaysia Sarawak. The identified and certified plant materials were given a voucher number as IJU/2016/15010238 (Hornstedtia scyphifera var.) and The fresh leaves from the plant was carefully plucked and washed under running tap water. It was then air dried to be free of water and then spread in the laboratory and allow to dry at room temperature until they were fully dried.

\subsubsection{Sample Preparation}

Dried plant materials (leaves) were ground into fine powder form using laboratory pestle and mortar and electric grinder. The finely ground powdered samples (mesh 30) were packed into clean, dry sample containers and were labelled appropriately and kept for further use. Extraction was carried out by the conventional solvent extraction method described by Fasihuddin et al. (2010) and Isaac et al, (2018). This was achieved by soaking the ground plant material in solvents in the order of increasing polarity as shown in Figure 2. A total of $2 \mathrm{~kg}$ of the dried and ground powdered sample was extracted using cold soaking method with hexane. The sample were soaked in the hexane with the ratio of 1:3 (sample: hexane) in a 5 liters Erlenmeyer flasks at room temperature for 7 days. The resulting hexane solution was then filtered using Whatman filter paper No 4 and the residue was then re-extracted with fresh hexane for another $72 \mathrm{hrs}$ and filtered. Both extracts were combined and evaporated to dryness with a rotary evaporator (Heidolph Laborota 4000 efficient) under reduced pressure below $50{ }^{\circ} \mathrm{C}$ to obtain the hexane crude extract. The residue was reextracted using similar procedure with dichloromethane, chloroform, followed by ethyl acetate and methanol to obtain respective crude extracts. The dry weight and percentage yield of each crude extract were determined (simple percentage).

\subsection{Isolation and Identification of Secondary Metabolites}

\subsubsection{Isolation and Purification}

\section{Column Chromatography}

The basic principle of column chromatography is to separate a mixture of metabolites based on their molecular weight and polarity. A glass column of size 40/34 (large) was used for chromatography, and the sorbent used was silica gel 60 (Merck 70-230 Mesh ASTM $0.0630 .200 \mathrm{~mm}$ ). Silica gel slurry was prepared by dissolving silica gel (150 g) with suitable solvent, usually hexane. The column was prepared by pouring a slurry mixture of silica gel and solvent, into a glass column and allow it to settle down (Firdous et al., 2013). The packed column was left overnight before 4-10 g of sample was introduced onto the top of the packed column via wet-packing method or dry-packing method. The column was eluted with suitable solvent systems with increasing polarity (Fasihuddin et al., 2010). The column's valve was then opened and about 10-30 mL fraction of the solvent coming out from the column was collected in test tubes (Patra et al., 2012). The procedure was repeated by using different solvent systems, based on increasing polarity (Table 1). Samples from the column fractions were examined by using TLC plates in few suitable solvent systems to obtain the retention factor $\left(\mathrm{R}_{\mathrm{f}}\right)$ of any components that appeared as spots. Fractions with similar $\mathrm{R}_{\mathrm{f}}$ values were combined (Patra et al., 2012). Fractions which contain more than one component were further isolated and purified by using smaller glass column of sizes $24 / 29$ (medium) or 14/23 (small) with suitable solvent systems.

Fraction with single component (one spot) that appeared in TLC plate was treated as possible pure secondary metabolite. The combined fractions which contained the same single component was then allowed to air-dried or evaporated to dryness to obtain a pure secondary metabolite. 
Table 1 Organic solvent systems used as eluting solvents for column chromatography

\begin{tabular}{|c|c|c|c|}
\hline $\mathbf{S} / \mathbf{n}$ & Solvent & Volume to volume ratio $(\mathrm{v} / \mathrm{v})$ & Volume (mL) \\
\hline 1 & Hexane & 1 & 200 \\
\hline 2 & Hexane: DCM & $19: 1$ & 200 \\
\hline 3 & Hexane: DCM & $15: 1$ & 200 \\
\hline 4 & Hexane: DCM & $9: 1$ & 200 \\
\hline 5 & Hexane: DCM & $5: 1$ & 200 \\
\hline 6 & Hexane: DCM & $1: 1$ & 200 \\
\hline 7 & DCM & 1 & 200 \\
\hline 8 & DCM: $\mathrm{CHCl}_{3}$ & $19: 1$ & 200 \\
\hline 9 & DCM: $\mathrm{CHCl}_{3}$ & $15: 1$ & 200 \\
\hline 10 & DCM: $\mathrm{CHCl}_{3}$ & $9: 1$ & 200 \\
\hline 11 & DCM: $\mathrm{CHCl}_{3}$ & $5: 1$ & 200 \\
\hline 12 & DCM: $\mathrm{CHCl}_{3}$ & $1: 1$ & 200 \\
\hline 13 & $\mathrm{CHCl}_{3}$ & 1 & 200 \\
\hline 14 & $\mathrm{CHCl}_{3}: \mathrm{EA}$ & $19: 1$ & 200 \\
\hline 15 & $\mathrm{CHCl}_{3}: \mathrm{EA}$ & $15: 1$ & 200 \\
\hline 16 & $\mathrm{CHCl}_{3}: \mathrm{EA}$ & $9: 1$ & 200 \\
\hline 17 & $\mathrm{CHCl}_{3}: \mathrm{EA}$ & $5: 1$ & 200 \\
\hline 17 & $\mathrm{CHCl}_{3}: \mathrm{EA}$ & $1: 1$ & 200 \\
\hline 18 & EA & 1 & 200 \\
\hline 20 & EA: $\mathrm{MeOH}$ & $19: 1$ & 200 \\
\hline 21 & EA: $\mathrm{MeOH}$ & $15: 1$ & 200 \\
\hline 22 & EA: $\mathrm{MeOH}$ & $9: 1$ & 200 \\
\hline 23 & $\mathrm{EA}: \mathrm{MeOH}$ & $5: 1$ & 200 \\
\hline 24 & EA: $\mathrm{MeOH}$ & $1: 1$ & 200 \\
\hline 25 & $\mathrm{MeOH}$ & 1 & 200 \\
\hline
\end{tabular}

\subsubsection{Thin Layer Chromatography (TLC)}

The eluents collected from column chromatography, were subjected to thin layer chromatography (TLC) analysis. TLC was carried out using the method described by Isaac et al. (2019). A glass capillary tube was used to apply samples on the TLC plates (size $6.6 \times 20 \mathrm{~cm}, 5 \times 20 \mathrm{~cm}$ ) repeatedly with a spot of about $0.3 \mathrm{~mm}$ in diameter. The TLC plate was then placed in a rectangular glass developing chamber with its lower marked edge $(1 \mathrm{~cm}$ from the base) dipped into a developing solvent below the mark where the samples were spotted. The plates were allowed to develop to the level of upper mark ( $4 \mathrm{~cm}$ from the base) and then removed and dried. The TLC plates were then viewed directly for colored compounds, it was also viewed under UV box for UV fluorescent compound and stained with vanillin for compound that are neither visible nor UV fluorescence. Fractions containing similar characteristics were combined and dried. 


\subsection{Chemical Structure Elucidation}

\subsubsection{Gas Chromatography - Mass spectrometry (GC-MS)}

Gas chromatography (GC) analysis of fractions that were obtained from TLC as single spot was performed using a Shimadzu GC-Mass Spectrometry model QP2010 plus, equipped with a BPX-5 column (5\% phenyl polysylphenlenesiloxane) of $30 \mathrm{~m}$ in length, film thickness of $0.25 \mu \mathrm{m}$ and internal diameter of $0.25 \mathrm{~mm}$. The operating method was based on the method described by Umaru et al. (2019). Ionization energy of $70 \mathrm{eV}$ was used in the electron ionization energy system of the GC-MS for detection and carrier gas, helium (99.999\%) at a constant flow rate of $1 \mathrm{~mL}$ per min was used. Exactly $1 \mu \mathrm{L}$ of purified sample was injected into the GC-MS using a syringe and sample was analysed using split mode with ration of 25:1. Injection temperature was set at $260{ }^{\circ} \mathrm{C}$ and the oven temperature was programmed from $60^{\circ} \mathrm{C}$ with an increase of $10^{\circ} \mathrm{C}$ per min, isothermal for $5 \mathrm{~min}$, to $2800^{\circ} \mathrm{C}$, ending with 10 min isothermal at $280{ }^{\circ} \mathrm{C}$ at $70 \mathrm{eV}$. Mass spectra was taken at a scan interval of $0.5 \mathrm{sec}$ and fragments from 45 to $450 \mathrm{Da}$. By matching its average peak area to the total areas, the relative percentage quantity of each component was acquired. Compound identification was obtained by matching the retention times of the compounds and the mass spectral obtained from the library data of the corresponding compound.

\subsubsection{Fourier Transform Infra-Red Spectrometry (FT-IR)}

Fourier Transform Infra-Red (FT-IR) was performed using FTIR spectroscopy (Thermos Scientific, Nicolet iS10 SMART iTR) to detect the chemical bonds (functional groups) of the compounds. The operating system was based on the method described by Umaru et al., (2019). The liquid samples were introduced into the machine and scan range was set from 400 to $4000 \mathrm{~cm}^{-1}$ with a resolution of $4 \mathrm{~cm}^{-1}$. Characteristic of the chemical bonds was read by spectrum produced through transmittance of wavelength of light. The chemical bond in a molecule were detected by interpreting the infrared transmittance spectrum and the functional groups of the compounds were identified based on the Table of Characteristic IR absorptions published in Organic Chemistry (Janice, 2008).

\subsubsection{Nuclear Magnetic Resonance (NMR)}

Nuclear Magnetic Resonance (NMR) spectrometry was performed using JEOL JNM-ECA 500 Spectrometer. The operating system was based on the method described by Efdi et al. (2010). Sample was dissolved in $0.8 \mathrm{~mL}$ chloroform D1 ( $\left.\mathrm{CDCl}_{3}\right)$ or Acetone D6 and placed into NMR tube to a sample depth of $4 \mathrm{~cm}$ and the ${ }^{1} \mathrm{H}(500 \mathrm{MHz})$ and ${ }^{13} \mathrm{C}(125 \mathrm{MHz})$ spectra were measured. Chemical shifts were reported as $\delta$ units (ppm) with tetramethysilane (TMS) as internal standard and coupling constants $\left(\right.$ ) in Hz. Integration of the ${ }^{1} \mathrm{H}-\mathrm{NMR}$ and ${ }^{13} \mathrm{C}-\mathrm{NMR}$ data was performed by using DELTA version 5.0.4 software by JEOL. The identification of each ${ }^{1} \mathrm{H}-\mathrm{NMR}$ and ${ }^{13} \mathrm{C}-\mathrm{NMR}$ detected was based on the Table of Characteristic NMR absorptions published in Organic Chemistry (Janice, 2008) and with the guide of the possible proposed structure given by NIST library.

\subsection{Melting Point}

The melting point of the compounds isolated was determined using a melting point apparatus (Stuat model SMP3). Small amount of the sample was put into a small capillary tube and was inserted into the machine melting point heating bath. The heating process was monitored and the temperature at which the sample begins to melt and completely melted was recorded.

\subsection{Antimicrobial Activity}

\subsubsection{Microorganisms}

Bacterial strains Escherichia coli (E. coli), Klebsielia pneumonia (K. pneumonia), Salmonella typhii (S. typhii) and Staphylococcus aureus (S. aureus) were selected for the study. The bacterial strains were obtained from the Microbiology Laboratory, Faculty of Resource Science and Technology, Universiti Malaysia Sarawak, and were used for the antibacterial activities. The stock cultures were incubated at $37^{\circ} \mathrm{C}$ for $24 \mathrm{hrs}$ on nutrient agar (Microcare Laboratory, Surat, India), and was stored at $4{ }^{\circ} \mathrm{C}$. Plates containing Mueller-Hinton Agar (MHA) were used to grow the bacterial strains at $37^{\circ} \mathrm{C}$. The stock cultures were then kept at $4^{\circ} \mathrm{C}$ until use.

\subsubsection{Antibacterial assay}

Antibacterial activity of leaf Hornstedtia scyphifera var was determined against four pathogenic bacterial strains E. coli, K. pneumonia, S. typhii and S. aureus using disk diffusion method as reported by various authors (Boyan et al., 2005; Prashanth et al., 2006). The extract was dissolved using dimethyl sulfoxide (DMSO) and sterilized by filtration and stored at $4{ }^{\circ} \mathrm{C}$ until use. Standard antibiotics (tetracycline) was used for comparison of the zone of inhibition of the pure 
strains of the bacteria. The extracts were then screened for their antibacterial activity against the bacterial strains. Set of five dilutions for antibacterial activity $(25,50,100,250,500 \mu \mathrm{g} / \mathrm{mL})$ of the leaf extracts of Hornstedtia scyphifera var. and standard drug (tetracycline) was prepared in distilled water. Sterile plates containing Mueller-Hinton agar were seeded with indicator bacterial strains and control experiment using tetracycline as standard drug were kept for $3 \mathrm{hrs}$ at $37{ }^{\circ} \mathrm{C}$. They were then incubated for 18 to $24 \mathrm{hrs}$ at $37{ }^{\circ} \mathrm{C}$, and the zones of growth inhibition around the disks were measured in $\mathrm{mm}$. The antibacterial activity of the test organisms on the plant extracts were determined by measuring the diameter of the inhibitory zones on the surface of the agar around the disk, and the values $<9$ mm were considered as not active against the microorganism for antibacterial activity (Prashanth et al., 2006). The experiment was carried out in triplicate and the mean values of the diameter of zones of inhibition was calculated using statistical software SPSS 22.

\subsubsection{Brine shrimp (Artemia salina) Lethality Test}

The $\mathrm{LC}_{50}$ of the plant extracts was determined using brine shrimp lethality test. The test was conducted using larvae of Artemia salina based on method developed by McLaughlin et al. (1991). One spatula full of brine eggs was placed into a $250 \mathrm{~mL}$ beaker containing $150 \mathrm{~mL}$ of sea water placed under light environment. A source of $\mathrm{O}_{2}$ supply was connected to the beaker using water pump at reduced pressure and allowed for $72 \mathrm{hrs}$ to hatch. The brine shrimp (nauplii) were then used for the test. Exactly $4 \mathrm{mg}$ of each extract was dissolved in $200 \mu \mathrm{L}$ of DMSO (RCI Labscan limited) and a lower series of chosen concentration was prepared by serial dilution with DMSO. The assay system was prepared with $5 \mathrm{~mL}$ of filtered seawater containing chosen concentration of extract and 1\% yeast extract (for feeding) in a pre-marked 6well microplate and 10 brine shrimps were carefully taken with micropipette and introduced into each microplate. This was done in triplicates making a total of 30 brine shrimps per concentration. Filtered seawater was added to DMSO and 10 brine shrimps in triplicates and this was used as the control groups. If the brine shrimp in these microplates shows a rapid mortality rate, then the test is considered invalid as the nauplii might have died due to some reasons other than the cytotoxicity of the extracts. The setup was allowed to remain for $24 \mathrm{hrs}$ under constant illumination of fluorescent and number of survived nauplii were counted with a hand lens. Based on the data obtained, the average death of the brine shrimp at different concentrations of the extract and the $\mathrm{LC}_{50}$ of the extract was calculated using probit regression by statistical software SPSS 22 and the result was expressed as Mean + SD at the 95\% level of confidence $(p<0.05)$.

\subsection{DPPH (2,2-diphenyl-1-picryl-hydrazyl) Free Radical Scavenging Assay (Antioxidant)}

The free radical scavenging assay of compound 2,2-diphenyl-1-pycryl-hydrazyl (DPPH) was used to evaluate the antioxidant properties of the crude extract. The measurement was based on the method described by Wang et al. (2008). The sample was prepared by diluting $6 \mathrm{mg}$ of crude extract into $6 \mathrm{~mL}$ of methanol, producing a concentration of 1000 $\mu \mathrm{g} / \mathrm{mL}$. The stock solution was sonicated to ensure the homogeneity of the sample. Three other concentrations were prepared at 10, 50 and $100 \mu \mathrm{g} / \mathrm{mL}$, diluted from the $1000 \mu \mathrm{g} / \mathrm{mL}$ stock solution. Sample of $5000 \mu \mathrm{g} / \mathrm{mL}$ was prepared separately by diluting $25 \mathrm{mg}$ of crude extract into $5 \mathrm{~mL}$ of methanol.

Approximately $3 \mathrm{~mL}$ of $0.1 \mathrm{mM}$ solution of 2,2-diphenyl-1-pycrylhydrazyl (DPPH) in methanol was each added into five series of prepared concentrations $(10,50,100,1000$ and $5000 \mu \mathrm{g} / \mathrm{mL})$ of sample solutions $(1 \mathrm{~mL})$. Analysis was done in triplicate. The solution was mixed vigorously and left to stand at room temperature for 30 minutes in the dark after which its absorbance was measured spectrophotometrically at $517 \mathrm{~nm}$ using Jasco ultra violet spectrophotometer model V-630. Methanol was used as blank (only methanol) and negative control (1 mL methanol mixed with $3 \mathrm{~mL}$ DPPH), while ascorbic acid (vitamin C) as the standard. The concentration of the sample required to inhibit $50 \%$ of the DPPH free radical was calculated as $\mathrm{IC}_{50}$ and the value was determined using Log dose inhibition curve which performed by using PRISM version 3.02 software, based on the calculated values of the DPPH scavenging activity (\%) of the sample (Tailor \& Goyal, 2014).

\subsection{Physical Properties and Spectrometry Information of Pure Compounds}

Quercetin (1) is a light yellow solid when dried with a melting point at $322-324{ }^{\circ} \mathrm{C}$ with molecular formula $\mathrm{C}_{15} \mathrm{H}_{10} \mathrm{O}_{7 .:} \mathrm{IR}$ Vmax cm${ }^{-1}: 3347 \mathrm{~cm}^{-1}, 2973 \mathrm{~cm}^{-1}, 2880 \mathrm{~cm}^{-1}, 1655.81 \mathrm{~cm}^{-1}, 1453.73 \mathrm{~cm}^{-1}, 1328.68 \mathrm{~cm}^{-1} 1082.11 \mathrm{~cm}^{-1} 879.60 \mathrm{~cm}^{-1}, 646.30$ $\mathrm{cm}^{-1}$ : MS m/z (\% rel. int): 45 (8), 55 (9), 75 (100), 89 (5), 101 (2), 113 (3), 129 (2), 141 (1), 155 (1), 181 (1), 195 (1), 213 (1), 227 (1), 239 (1), 252 (1), 267 (1), 285 (1), 302 (30), 328 (1), 347 (1), 362 (1), 388 (1), 407 (1), 428 (1), 445 (1), 468 (1), 482 (1), 500 (1), 514 (1), 545 (1). ${ }^{1} \mathrm{H}-\mathrm{NMR}\left(500 \mathrm{MHz}, \mathrm{CDCl}_{3}\right) \delta(\mathrm{ppm}): 8.94$ (1H, s), 6.19 (1H, s), 6.12 (1H, d, =6.15), $0.70(1 \mathrm{H}, \mathrm{s}), 6.13(1 \mathrm{H}, \mathrm{d}, \mathrm{J}=6.12), 6.91(1 \mathrm{H}, \mathrm{s}), 3.43(1 \mathrm{H}, \mathrm{s}), 6.71(1 \mathrm{H}, \mathrm{t}, \mathrm{J}=6.71), 6.93(1 \mathrm{H}, \mathrm{t}, \mathrm{J}=6.92):{ }^{13} \mathrm{C}-\mathrm{NMR}$ (125 MHz, CDCl $) \delta(\mathrm{ppm}): 146.35$ (C-1), 137.09 (C-2), 175.24 (C-4), 104.28 (C-6), 159.95 (C-7), 90.62 (C-9), 164.13 (C10), 94.42 (C-12), 157.59 (C-13), 121.81 (C-15), 115.98 (C-16), 145.29 (C-17), 148.35 (C-19), 116.29 (C-21), 121.63 (C22). 
Dedocanoic acid (2) is a light yellow solid when dried with a melting point at $44.6{ }^{\circ} \mathrm{C}$ with molecular formula $\mathrm{C}_{12} \mathrm{H}_{24} \mathrm{O}_{2}$.: IR Vmax cm-1: $3341.62 \mathrm{~cm}^{-1}, 2974.22 \mathrm{~cm}^{-1}, 1653.34 \mathrm{~cm}^{-1}, 1384.78 \mathrm{~cm}^{-1} 1086.68 \mathrm{~cm}^{-1} 1044.08 \mathrm{~cm}^{-1}, 878.61 \mathrm{~cm}^{-1}: \mathrm{MS} \mathrm{m} / \mathrm{z}$ (\% rel. int): 45 (19), 55 (70), 60 (99), 78 (100), 87 (51), 110 (15), 136 (22), 143 (42), 157 (34), 171 (54), 185 (30), 200 (15), 229 (10), 264 (18), 280 (8), 305 (6), 320 (6), 348 (4), 369 (3), 383 (5), 402 (5), 414 (5), 429 (5), 446 (6), 461 2), 474 (2), $498(2), 510(3), 529(1) .{ }^{1} \mathrm{H}-\mathrm{NMR}\left(500 \mathrm{MHz}, \mathrm{CDCl}_{3}\right) \delta(\mathrm{ppm}): 2.28(2 \mathrm{H}, \mathrm{m}), 1.63(2 \mathrm{H}, \mathrm{m}), 1.33(2 \mathrm{H}, \mathrm{m}), 1.32(2 \mathrm{H}$, $\mathrm{m}), 1.31(2 \mathrm{H}, \mathrm{m}), 1.31(2 \mathrm{H}, \mathrm{m}), 1.31(2 \mathrm{H}, \mathrm{m}), 1.31(2 \mathrm{H}, \mathrm{m}), 1.30(2 \mathrm{H}, \mathrm{m}), 1.37(2 \mathrm{H}, \mathrm{m}), 0.99(3 \mathrm{H}, \mathrm{t}, \mathrm{J}=56), 9.47(1 \mathrm{H}, \mathrm{s}) .{ }^{13} \mathrm{C}-$ NMR (125 MHz, CDCl $) \delta(\mathrm{ppm}): 177.13$ (C-1), 34.35 (C-2), 24.81 (C-3), 28.93, (C-4), 28.96 (C-5), 28.96 (C-6), 28.96 (C7), 28.96 (C-8), 29.06 (C-9), 31.65 (C-10), 22.94 (C-11), 14.02 (C-12).

\section{Results and discussion}

\subsection{Purification and Structural Elucidation of Secondary Metabolites}

\subsubsection{Purification of Compounds 1, and 2 from methanol Hornstedtia scyphifera var Leaf extract}

Compounds 1 and 2 were isolated from methanol crude extract of Hornstedtia scyphifera var Leaf extract. About $20 \mathrm{~g}$ of the crude extract was loaded using dry pack method into a column packed with silica gel in hexane (100\%). The crude extract was then eluted from the column with solvent system in the sequence as indicated in Table 1.

Table 2 Fractions collected from methanol crude leaf extract of Hornstedtia scyphifera

\begin{tabular}{lcll}
\hline $\begin{array}{l}\text { Code } \\
\text { Fraction }\end{array}$ & of & $\begin{array}{l}\text { Weight } \\
\text { Fraction (mg) }\end{array}$ & $\begin{array}{c}\text { of } \\
\text { Colour } \\
\text { Fraction }\end{array}$ \\
\hline HSMtol 1 & 8.16 & Colourless \\
HSMtol 2 & 10.39 & Colourless \\
HSMtol 3 & 18.5 & Light yellow \\
HSMtol 4 & 79.5 & Light yellow \\
HSMtol 5 & 105.2 & Brown \\
HSMtol 6 & 225.8 & Brown \\
HSMtol 7 & $\mathbf{1 8 0 . 6}$ & Dark brown \\
HSMtol 8 & 333.3 & Dark brown \\
HSMtol 9 & $\mathbf{2 2 0 . 9}$ & Dark brown \\
HSMtol 10 & 290.7 & Dark brown \\
HSMtol 11 & 530.0 & Dark brown \\
HSMtol 12 & 230.8 & Dark brown \\
\hline
\end{tabular}

\subsubsection{Purification and Structural Elucidation of Compound 1}

Purification

Compound 1 was isolated from combined fraction HSMtol 9 of 220.9 mg dark brown. TLC analysis of the combined fraction HSMetol 9 was carried out in different solvent system. It was observed under UV light and recorded as shown in Table 3. 
Table $3 \mathrm{R}_{\mathrm{f}}$ values of combined fraction HSMtol 9 in different solvent system under UV light

\begin{tabular}{lcc}
\hline Solvent system (v/v) & Number of spots & Rf values \\
\hline Hexane: DCM (7:3) & 2 & 0.32 \\
& 2 & 0.11 \\
Hexane: CHCl3 (8:2) & & 0.46 \\
Hexane: EA (4:1) & 2 & 0.40 \\
& & 0.68 \\
\hline
\end{tabular}

Light colored spots seen under UV light with the same Rfvalues collected from fractions HSMtol 9-1 to HSMtol 9-15 were targeted and were combined, and it was labelled as HSMtol 9- A. Separation using small column of combined fractions HSMtol 9-A was performed and combined fraction HSMtol 9-A1 was obtained, it was then separated using small column and combined fraction HSMtol 9-A2 was obtained. Preparative TLC analysis of the combined faction HSMtol 9-A2 was performed in the solvent systems hexane: chloroform (8:2) which gave a good separation from the other spots present. The targeted spot was labelled as HSMtol 9-A3. TLC analysis of HSMtol 9-A3 was performed in different solvent systems and the result obtained under UV light and vanillin staining showed 2 spots as shown in Table 4.

Table 4 Rf values of combined fraction HSMtol 9-A3 in different solvent system under UV light

\begin{tabular}{lll}
\hline Solvent system (v/v) & Number of spots & Rf values \\
\hline Hexane: CHCl3 (8:2) & 2 & 0.56 \\
& & 0.44 \\
Hexane: EA (9:1) & 2 & 0.60 \\
& & 0.21 \\
\hline
\end{tabular}

HSMtol 9-A3 was further purified in a smaller column using the solvent system hexane: chloroform (8:2) which gives a better separation as examined on the TLC profile. Fractions with similar $\mathrm{R}_{\mathrm{f}}$ values of the targeted spots were combined and labelled as HSMtol 9-A4. TLC analysis of HSMtol 9-A4 was performed in different solvent systems and the spot obtained with its $\mathrm{R}_{\mathrm{f}}$ value was recorded as shown in Table 5.

Table $5 \mathrm{R}_{\mathrm{f}}$ values of combined fraction HSMtol 9-A4 in different solvent system under UV light

\begin{tabular}{lcl}
\hline Solvent system $(\mathbf{v} / \mathbf{v})$ & Number of spots & $\mathbf{R}_{\mathbf{f}}$ values \\
\hline Hexane: chloroform $(8: 2)$ & 1 & 0.48 \\
\hline
\end{tabular}




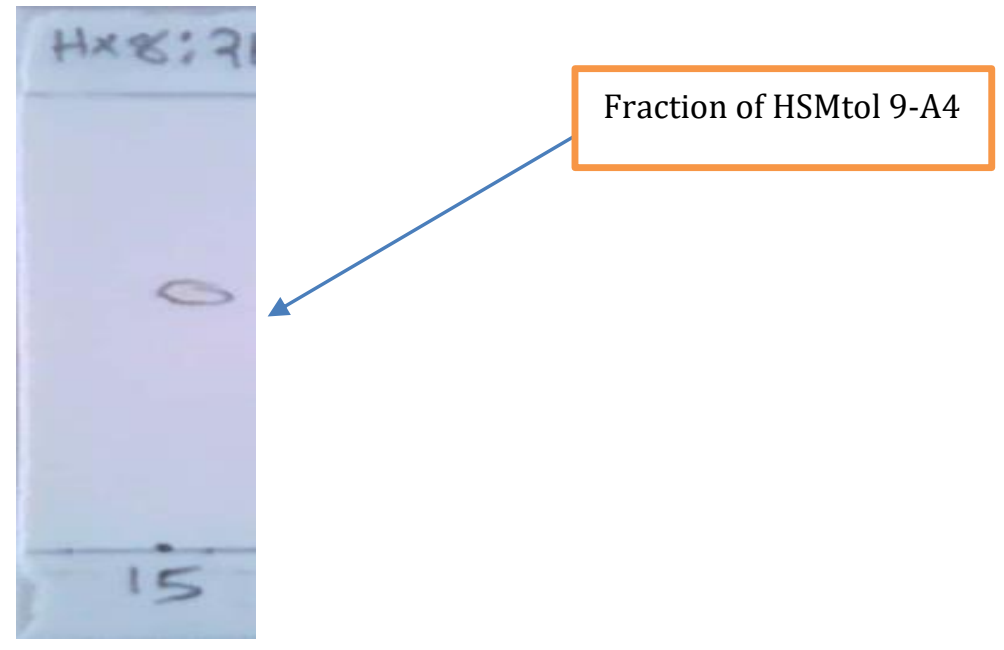

Figure 3 Shows the TLC profile for the combined fraction HSMtol 9-A4 in hexane: ethyl acetate (8:2) as a single spot which suggest that it is a pure compound.

GC analysis of the fraction of HSMtol 9-A4 was then carried out, and the result from the gas chromatogram (Figure 4) showed a single peak at a retention time of $24.48 \mathrm{~min}$. This confirmed that HSMtol 9-A4 is a pure compound and it was renamed as Compound 1.

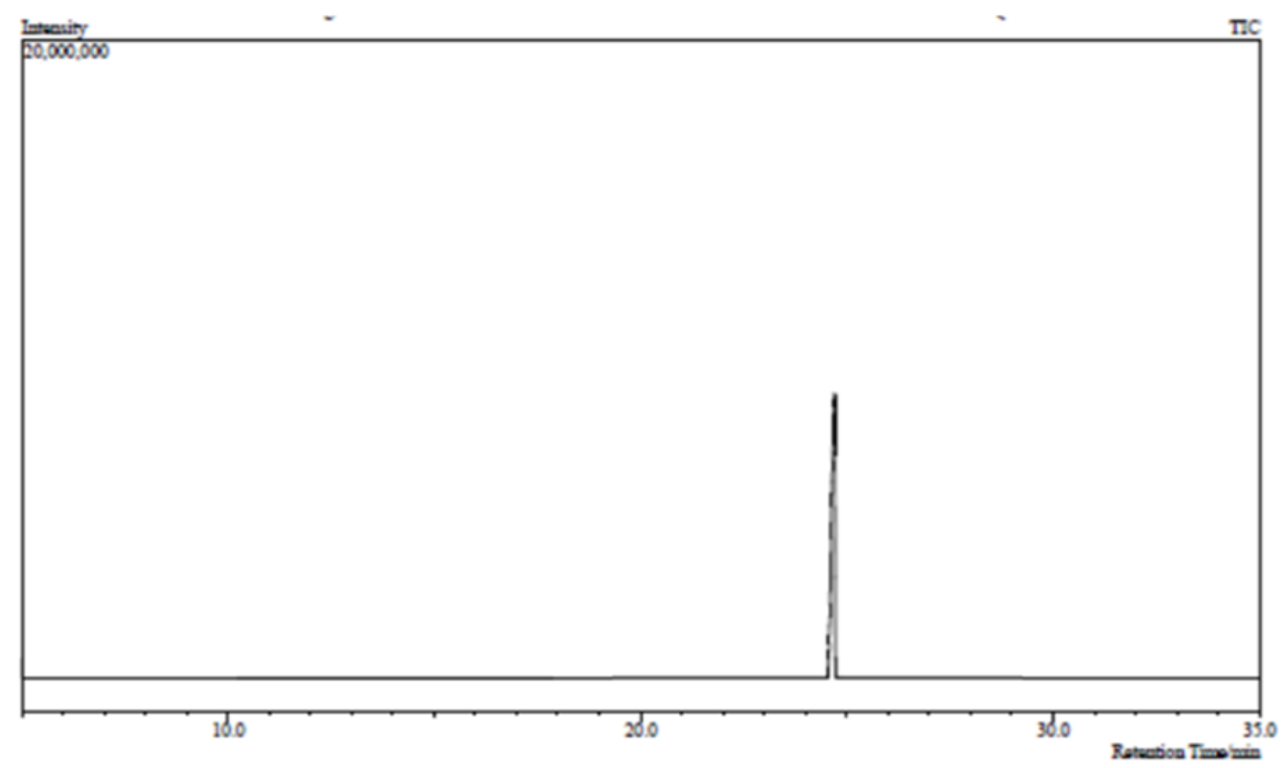

Figure 4 Gas chromatogram of Compound 1.

\subsubsection{Structural Elucidation}

Compound 1 was isolated from the methanol leaf crude extract of Hornstedtia scyphifera, with its physical appearance as a yellow crystal and a melting point at $322-324{ }^{\circ} \mathrm{C}$ with molecular formula $\mathrm{C}_{15} \mathrm{H}_{10} \mathrm{O}_{7}$. The mass spectrum of Compound 1 in Figure 5 shows a similarity index of $98.9 \%$ with the mass spectrum of the suggested structure of Compound 1 by the NIST library in Figure 6. On the mass spectrum of Compound 1 one of its molecular ion peak was observed at $m / z$ 302 which was found to correspond to the molecular ion peak and molecular ion weight of the suggested structure of Compound 1 by the NIST library which has a chemical formula of $\mathrm{C}_{15} \mathrm{H}_{10} \mathrm{O}_{7}$. Figure 4 also shows base peak for Compound 1 at $m / z 75$ which was observed in the mass spectrum of the suggested structure for Compound 1. 


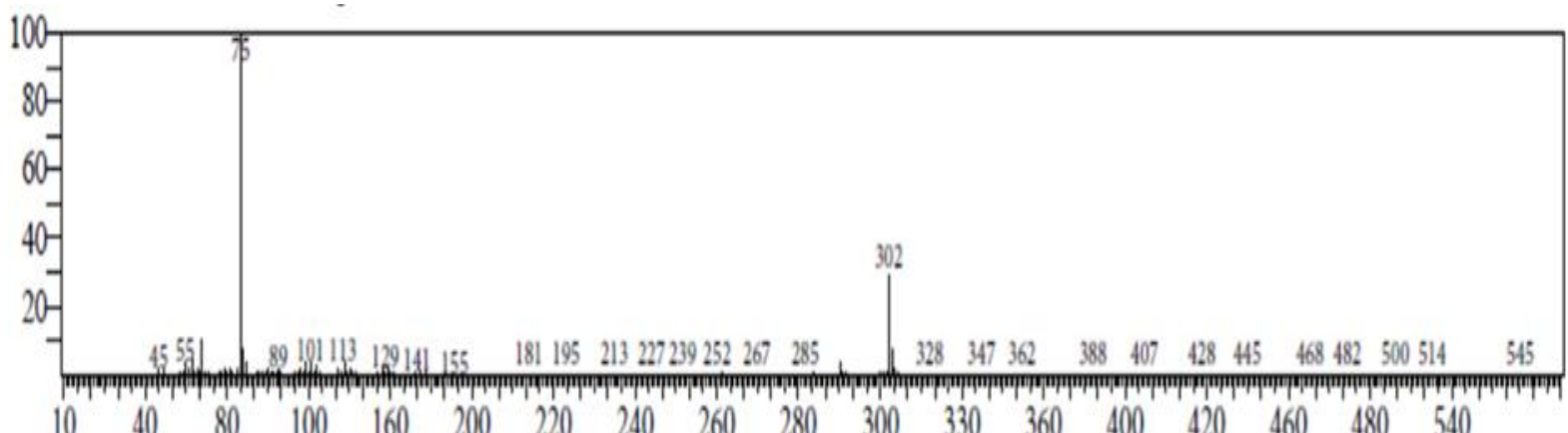

Figure 5 Mass spectrum of Compound 1.

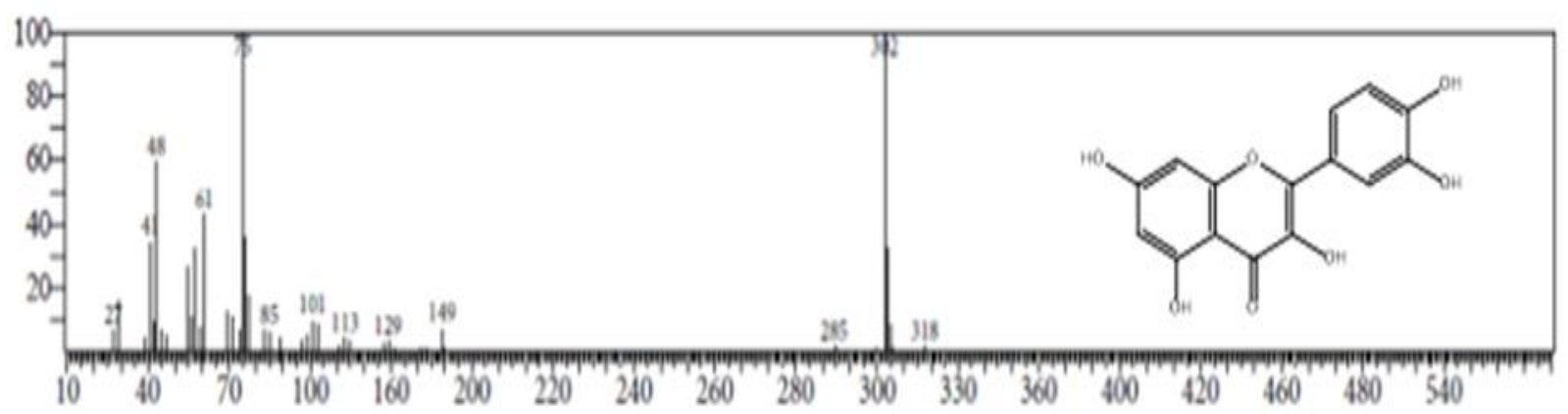

Figure 6 Mass spectrum of suggested structure of Compound 1 by NIST Library.

Chemical structure of Compound 1 consists of absorption bands of C-H which was observed at $2973 \mathrm{~cm}^{-1} \mathrm{and}_{2880 \mathrm{~cm}}^{-}$ 1 in the IR spectrum (Figure 7) and indicated the presence of methyl alkyl carbon in the chemical structure. A signal indicating the presence of double bond was observed at $1655 \mathrm{~cm}^{-1}$ which also matched the double bonds of $\mathrm{C}=\mathrm{C}$ in the ring, and another at $1453 \mathrm{~cm}^{-1}$ which may represent the $\mathrm{C}=\mathrm{C}$ bond in the asymmetry ring in the suggested structure of quercetin (1). A signal was observed at $1082 \mathrm{~cm}^{-1}$ which was seen to represent the C-O bond stretching and single bond of C-C stretching at $879 \mathrm{~cm}^{-1}$ were observed in the IR spectrum of Compound 1 (Figure 7). IR spectrum of Compound 1 also showed similarity to IR of the same proposed compound reported by Duc et al. (2018).

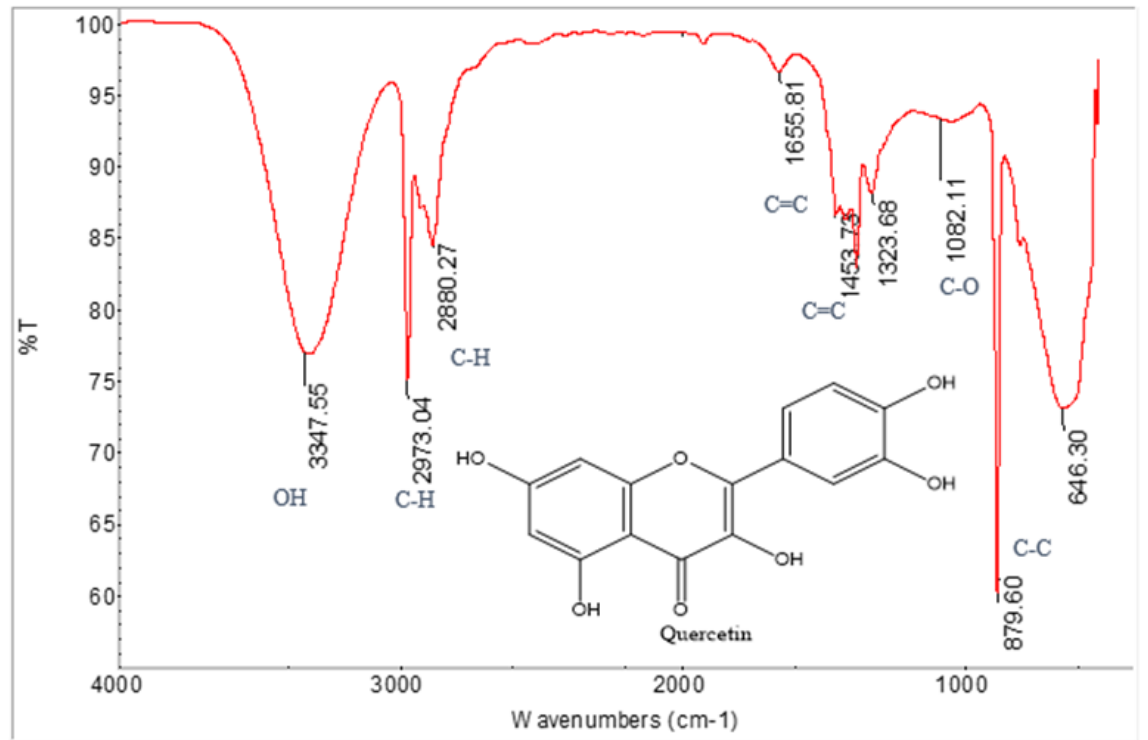

Figure 7 IR Spectrum of Compound 1 
NMR analysis was further performed for the elucidation of the chemical structure of Compound 1, and the results are shown in Figure $8\left({ }^{1} \mathrm{H}-\mathrm{NMR}\right)$ and Figure $9\left({ }^{13} \mathrm{C}-\mathrm{NMR}\right)$. Based on the table of ${ }^{1} \mathrm{H}-\mathrm{NMR}$ characteristics absorption and ${ }^{1} \mathrm{H}-$ NMR peaks splitting pattern as reported in Organic Chemistry by Janice (2008), the proton signals were all integrated and were assigned to every proton NMR of Compound 1 as the proposed chemical structure.

The result showed that ${ }^{1} \mathrm{H}-\mathrm{NMR}$ spectrum of Compound 1 exhibited 9 proton resonates. The ${ }^{1} \mathrm{H}-\mathrm{NMR}$ spectrum showed aromatic proton signals at $\delta \mathrm{H} 6.71(1 \mathrm{H}, \mathrm{d}, \mathrm{J}=6.71), 6.91(1 \mathrm{H}, \mathrm{d}, \mathrm{J}=6.92), 6.93(1 \mathrm{H}, \mathrm{d}, \mathrm{J}=6.92)$, two meta-coupled aromatic proton signals at $\delta \mathrm{H} 6.12(1 \mathrm{H}, \mathrm{d}, \mathrm{J}=6.15), 6.13(1 \mathrm{H}, \mathrm{d}, \mathrm{J}=6.12$,) and were assigned to $\mathrm{H}-21, \mathrm{H}-16, \mathrm{H}-22, \mathrm{H}-9$, and $\mathrm{H}-12$, respectively.

Figure 9 shows the result of the ${ }^{13} \mathrm{C}-\mathrm{NMR}$ spectrum of Compound 1. From the result every carbon NMR signal that was observed was assigned to the proposed chemical structure of Compound 1 which is based on the table of ${ }^{13} \mathrm{C}$-NMR characteristics absorption reported in Organic Chemistry by Janice (2008).

A total of 15 carbon resonates was observed in the spectrum. The ${ }^{13} \mathrm{C}$-NMR spectrum indicated that 5 has a flavonol skeleton with 15 carbons, including five aromatic $\mathrm{CH}$; ten quaternary carbons (one carbonyl, five $\mathrm{O}$ bearing, and four aliphatic), suggesting that it is 3,5,7,3',4'- pentahydroxyflavone, commonly known as quercetin. The down field region showed 13 carbon resonates at $\delta 146.35, \delta 137.09, \delta 175.24, \delta 104.28, \delta 159.95, \delta 164.13, \delta 157.59, \delta 121.81, \delta 115.98$, $\delta 145.29 \delta 148.35, \delta 116.29$ and $\delta 121.63$, respectively. They were assigned to C-1, C-2, C-4, C-6, C-7, C-10, C-13, C-15, C$16, \mathrm{C}-17, \mathrm{C}-19, \mathrm{C}-21$ and $\mathrm{C}-22$. At up field two carbon signal was observed at $\delta 90.62$ and $\delta 94.42$, they were assigned to C-9 and C-12 respectively.

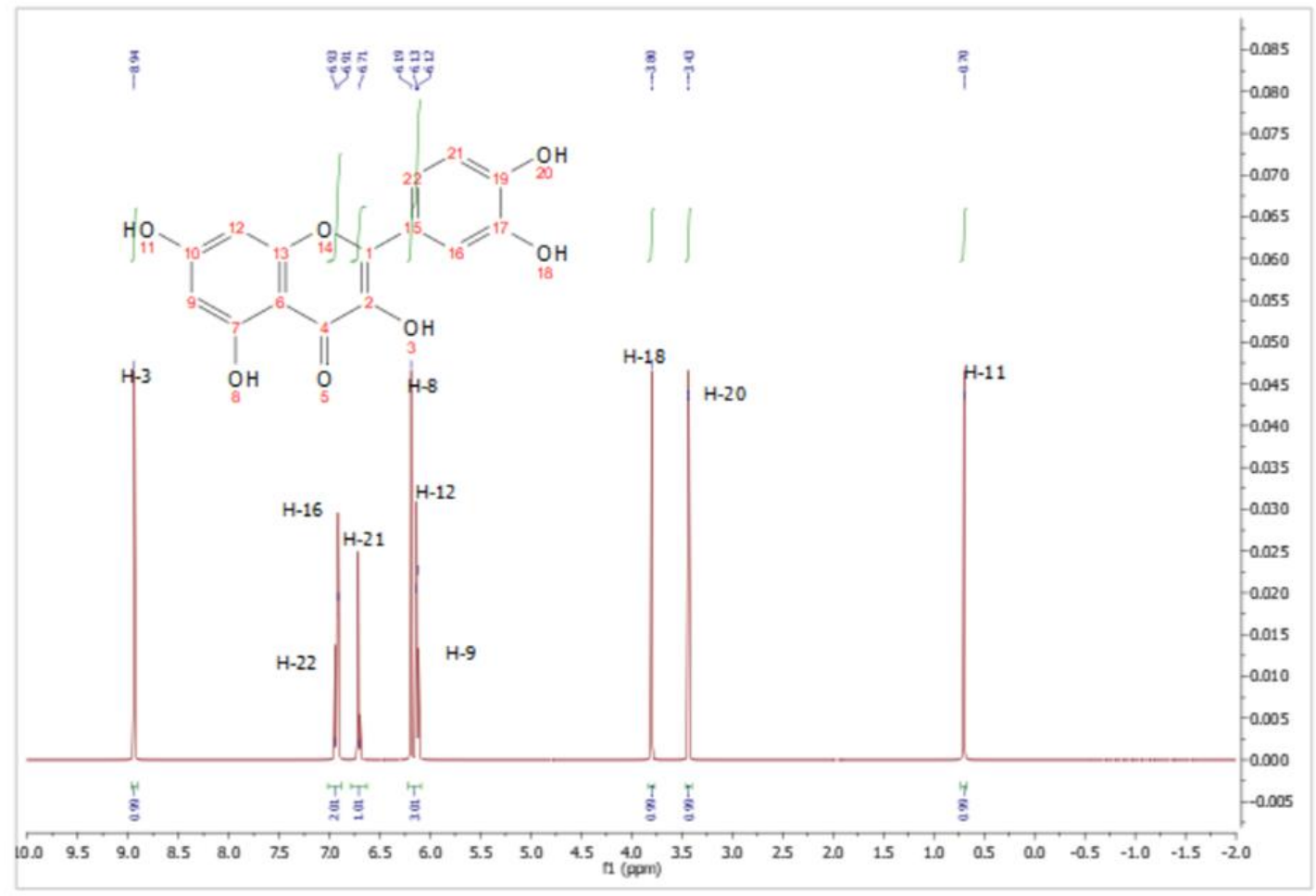

Figure $8^{1} \mathrm{H}-\mathrm{NMR}$ spectrum of Compound 1 (500 MHz, DMSO d6). 


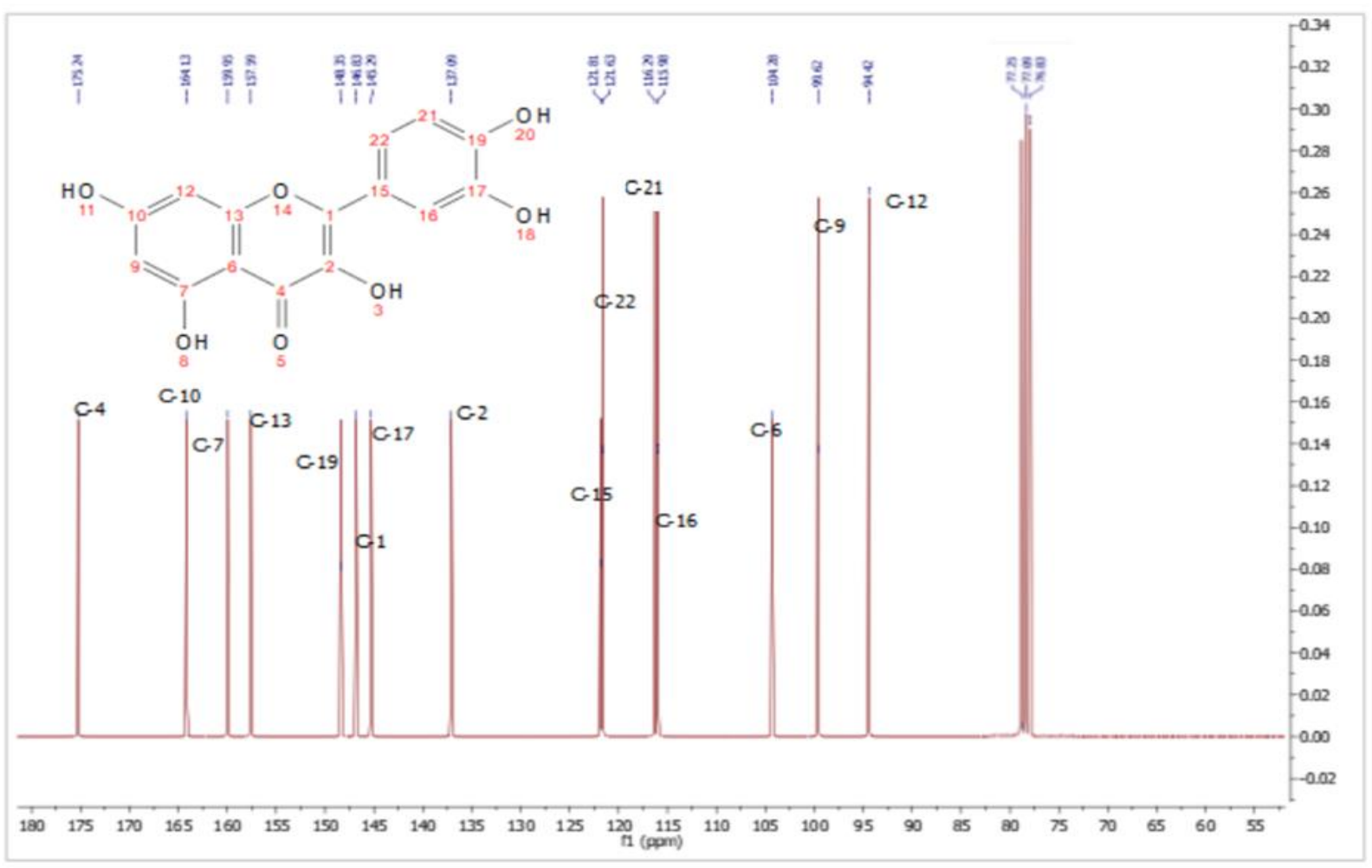

Figure 9 13C-NMR spectrum of Compound 1 (125 MHz, DMSO-d6)

Table 6 Proton NMR signal of Compound 1 and that reported by Duc et al. (2018).

\begin{tabular}{llll}
\hline $\begin{array}{l}\text { Proton } \\
\text { assigned to } \\
\text { Compound 1 }\end{array}$ & $\begin{array}{l}\text { Proton chemical shift } \\
\text { (ppm) of Compound 1 }\end{array}$ & $\begin{array}{l}\text { Proton assigned to } \\
\text { quercetin by Duc et al. } \\
\text { (2018) }\end{array}$ & $\begin{array}{l}\text { Proton chemical shift } \\
\text { (ppm) of quercetin (Duc } \\
\text { et al., 2018) }\end{array}$ \\
\hline $\mathrm{H}-3$ & $8.94(1 \mathrm{H}, \mathrm{s})$ & $\mathrm{H}-3$ & $\mathrm{OH}$ \\
$\mathrm{H}-8$ & $6.19(1 \mathrm{H}, \mathrm{s})$ & $\mathrm{H}-8$ & $\mathrm{OH}$ \\
$\mathrm{H}-9$ & $6.12(1 \mathrm{H}, \mathrm{d},=6.15)$ & $\mathrm{H}-9$ & $6.19(1 \mathrm{H}, \mathrm{d}, \mathrm{J}=2.0)$ \\
$\mathrm{H}-11$ & $0.70(1 \mathrm{H}, \mathrm{s})$ & $\mathrm{H}-11$ & $\mathrm{OH}$ \\
$\mathrm{H}-12$ & $6.13(1 \mathrm{H}, \mathrm{d}, \mathrm{J}=6.12)$ & $\mathrm{H}-12$ & $6.39(1 \mathrm{H}, \mathrm{d}, \mathrm{J}=2.0)$ \\
$\mathrm{H}-16$ & $6.91(1 \mathrm{H}, \mathrm{s})$ & $\mathrm{H}-16$ & $\mathrm{OH}$ \\
$\mathrm{H}-20$ & $3.43(1 \mathrm{H}, \mathrm{s})$ & $\mathrm{H}-20$ & $\mathrm{OH}$ \\
$\mathrm{H}-21$ & $6.71(1 \mathrm{H}, \mathrm{t}, \mathrm{J}=6.71)$ & $\mathrm{H}-21$ & $7.74(1 \mathrm{H}, \mathrm{d}, \mathrm{J}=2.0)$ \\
$\mathrm{H}-22$ & $6.93(1 \mathrm{H}, \mathrm{t}, \mathrm{J}=6.92)$ & $\mathrm{H}-22$ & $7.64(1 \mathrm{H}, \mathrm{dd}, \mathrm{J}=2.0,8.5)$ \\
\hline
\end{tabular}


Table 7 Carbon NMR signal of Compound 1 and that reported by Duc et al. (2018).

\begin{tabular}{|c|c|c|c|}
\hline $\begin{array}{l}\text { Carbon assigned to } \\
\text { compound } 1\end{array}$ & $\begin{array}{l}\text { Carbon chemical } \\
\text { shift (ppm) of } \\
\text { compound } 1\end{array}$ & $\begin{array}{l}\text { Carbon assigned to } \\
\text { quercetin (Duc et al., } \\
\text { 2018) }\end{array}$ & $\begin{array}{l}\text { Carbon chemical shift } \\
\text { (ppm) of quercetin } \\
\text { (Duc et al., 2018) }\end{array}$ \\
\hline C-1 & 146.35 & C-1 & 146.8 \\
\hline C-2 & 137.09 & $C-2$ & 135.6 \\
\hline$C-4$ & 175.24 & $C-4$ & 175.7 \\
\hline C-6 & 104.28 & C-6 & 103.0 \\
\hline$C-7$ & 159.95 & C-7 & 93.30 \\
\hline C-9 & 90.62 & C-9 & 163.80 \\
\hline$C-10$ & 164.13 & $\mathrm{C}-10$ & 98.10 \\
\hline$C-12$ & 94.42 & C-12 & 156.10 \\
\hline C-13 & 157.59 & C-13 & 121.90 \\
\hline$C-15$ & 121.81 & C-15 & 145.00 \\
\hline C-16 & 115.98 & C-16 & 147.6 \\
\hline $\mathrm{C}-17$ & 145.29 & C-17 & 115.5 \\
\hline C-19 & 148.35 & C-19 & 119.9 \\
\hline $\mathrm{C}-21$ & 116.29 & C-21 & 115.5 \\
\hline C-22 & 121.63 & C-22 & 119.9 \\
\hline
\end{tabular}

From the data obtained, the GCMS analysis of Compound 1 gave similarity index of $98.9 \%$ with the mass spectrum of the proposed compound by the NIST library which matched the characteristic of quercetin (1), with chemical formula $\mathrm{C}_{15} \mathrm{H}_{10} \mathrm{O}_{7}$. The melting point of Compound 1 is $322-324{ }^{\circ} \mathrm{C}$ Also, mass spectrum of Compound 1 is similar to the mass spectrum of the suggested structure by NIST library and is most probably identified quercetin (1). IR data reported by Duc et al. (2018) could be seen to match the IR data of Compound 1 which was reported as quercetin (1).

Based on mass spectrum, IR, ${ }^{1} \mathrm{H}-\mathrm{NMR}$ and ${ }^{13} \mathrm{C}-\mathrm{NMR}$ data and comparison with published literature (Duc et al., 2018) Compound 1 was therefore identified as quercetin (1).<smiles>O=c1nc(O)c2c(O)n(-c3cnc(O)nn3)oc(=O)n1-2</smiles>

Quercetin (1) is one major active constituent of many herbal plants, such as Kaempferia paviflora, Physalis peruviana linn, Piper caninum, and Leptospermum scoparium. The compound demonstrated many beneficial pharmacological effects in vitro, including anti-inflammatory, antioxidant properties (Bei and An, 2016).

\subsubsection{Purification and Structural Elucidation of Compound 2}

Purification

Compound 2 was isolated from the combined fraction HSMtol 7 of $180.6 \mathrm{mg}$ dark brown (Methanol crude leaf extract of Hornstedtia scyphifera) Table 2. TLC analysis of the combined fraction HSMtol7 was performed in different solvent systems and the result as observed under UV light was recorded as shown in Table 8. 
Table $8 \mathrm{R}_{\mathrm{f}}$ values of combined fraction HSMtol 7 in different solvent system under UV light

\begin{tabular}{lll}
\hline Solvent system (v/v) & Number of spots & Rf values \\
\hline Hexane: $\mathrm{CHCl} 3$ (3:2) & 3 & 0.75 \\
& & 0.61 \\
& & 0.58 \\
\hline Hexane: EA (7:3) & 3 & 0.62 \\
& & 0.61 \\
\hline DCM: EA (7:3) & 3 & 0.85 \\
& & 0.81 \\
& & 0.65 \\
\hline
\end{tabular}

Fractions containing a light yellowish spot were targeted and combined, it was labelled as HSMtol7-A. Combined fraction HSMtol 7-A. was then further purified two successive times in a smaller column using the solvent system hexane: ethyl acetate (7:3), and each fraction collected (HSMtol 7-A1 and HSMtol 7-A2) were observed under UV light and those containing the light yellowish spot were combined and labelled as HSMtol 7-A3. The Combined fraction HSMtol 7-A3 was then tested using TLC and observed under UV light. The result is shown in Table 9.

Table $9 \mathrm{R}_{\mathrm{f}}$ values of combined fraction HSMtol7-A3 in different solvent system under UV light

\begin{tabular}{lll}
\hline Solvent system (v/v) & Number of spots & Rf values \\
\hline Hexane: EA (7:3) & 2 & 0.63 \\
& & 0.60 \\
\hline DCM: EA (7:3) & 2 & 0.85 \\
& & 0.80 \\
\hline
\end{tabular}

Combined fraction HSMtol7-A3 was further purified using small column and fractions containing the targeted spots from HSMtol 7-A3 were then combined and labelled as HSMtol7-A4. Combined fraction HSMtol 7-A4 was further purified using the solvent system hexane: ethyl acetate (7:3), which gives a better separation. TLC of the fractions collected was performed and examined under UV light. Fractions containing the target spots were combined and labelled as HSMtol7-A5. TLC of the combined fraction HSMtol7-A5 was performed in different solvent system and the result was again examined under UV light as well as vanillin staining. It showed a single sport as shown in Table 10.

Table $10 \mathrm{R}_{\mathrm{f}}$ values of combined fraction HSMtol 7-A5 in different solvent system under UV light.

\begin{tabular}{lll}
\hline Solvent system $(\mathbf{v} / \mathbf{v})$ & Number of spots & Rf values \\
\hline Hexane: Ethyl acetate $(7: 3)$ & 1 & 0.62 \\
\hline
\end{tabular}

Figure 10 shows the TLC profile for the combined fraction HSMtol7-A5 in hexane: ethyl acetate (7:3) as a single spot which suggest that it is a pure compound 


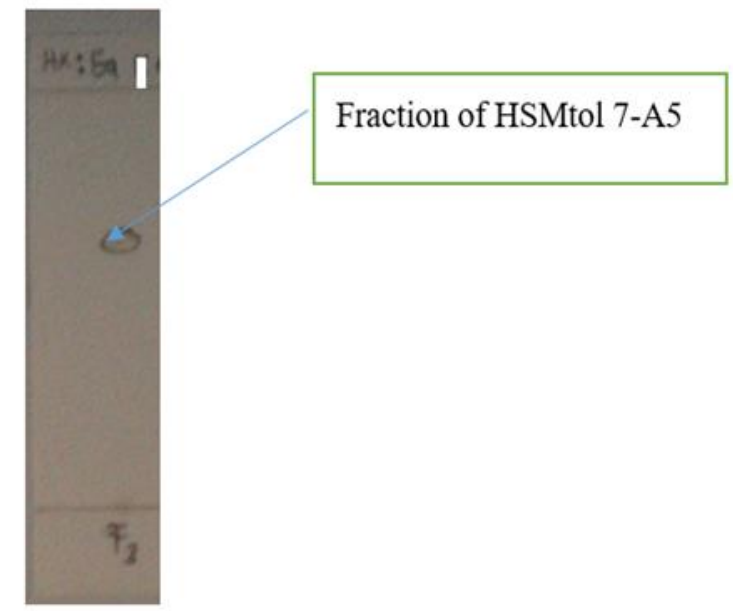

Figure 10 TLC plate showing the spot in combined fraction HSMtol 7-A5 in hexane: ethyl acetate (7:3)

Figure 10 show that combined fraction HSMtol7-A5 is a pure compound. GC analysis of the combined fraction HSMtol7A5 was then carried out, and the result from the gas chromatogram (Figure 11) showed a single peak at a retention time of 19.020 min. This confirmed that HSMtol 7-A5 is a pure compound and it was renamed as Compound 2. It is a white compound and $15 \mathrm{mg}$ was obtained.

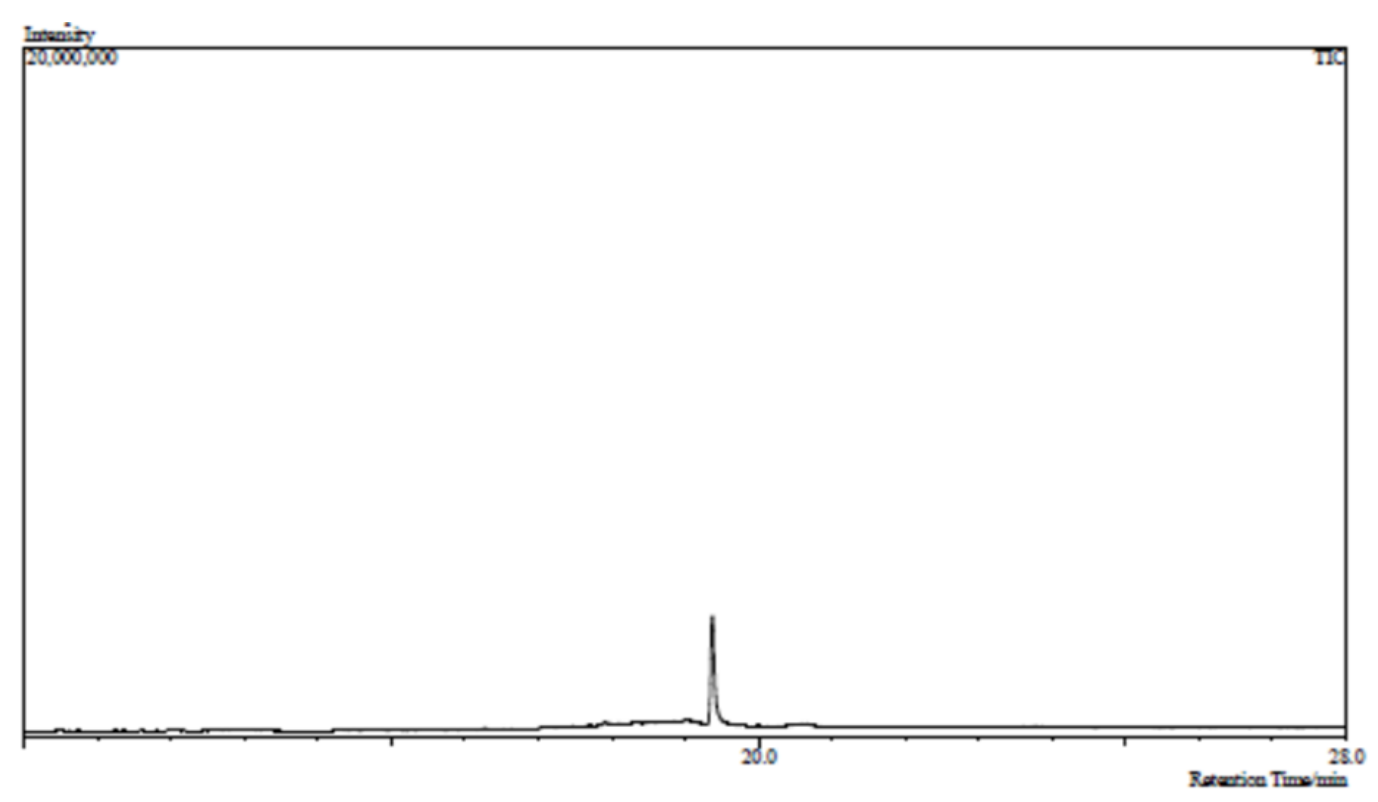

Figure 11 IR Spectrum of Compound 2

\subsubsection{Structural Elucidation}

Compound 2 was isolated from the methanol crude leaves extract of Hornstedtia scyphifera, its physical appearance as a light compound with a melting point of $44.6^{\circ} \mathrm{C}$. The mass spectrum of Compound 2 (Figure 12) show a similarity index of $96.5 \%$ with the mass spectrum of the compound suggested by the NIST library in Figure 13. The mass spectrum of Compound 2 showed an ion base peak which was observed at $m / z 73$ and a molecular ion peak of $m / z 73$ was also observed in the mass spectrum of the suggested structure of Compound 2. The mass spectrum of Compound 2 has one of its molecular ion peak observed at $\mathrm{m} / \mathrm{z} 200$, this corresponded to the same molecular ion peak and molecular ion weight of the suggested structure of Compound 2 by NIST library with a chemical formula of $\mathrm{C}_{12} \mathrm{H}_{24} \mathrm{O}_{2}$. 


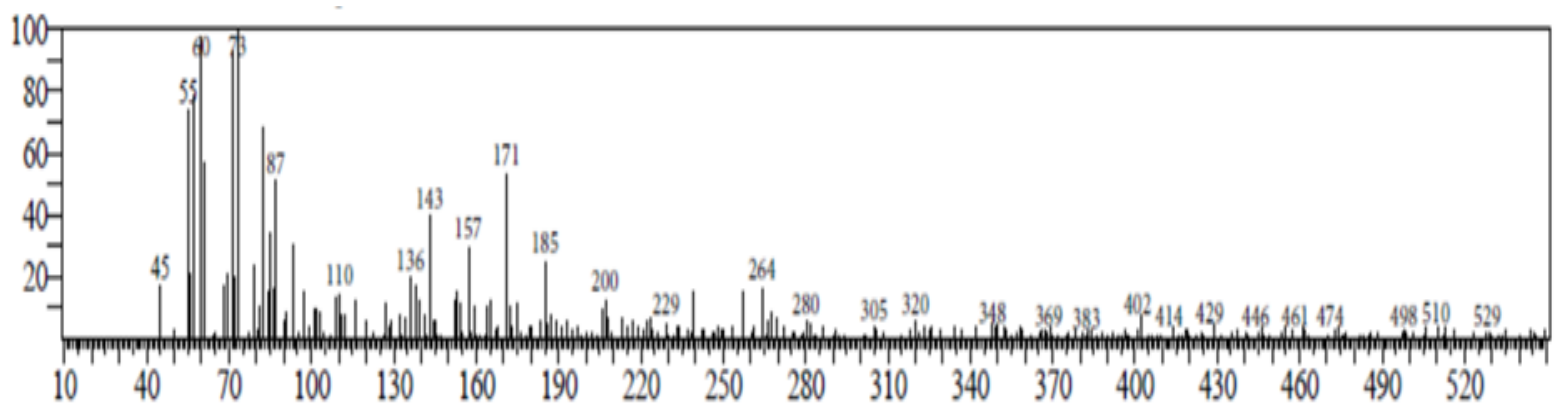

Figure 12 Mass spectrum of Compound 2

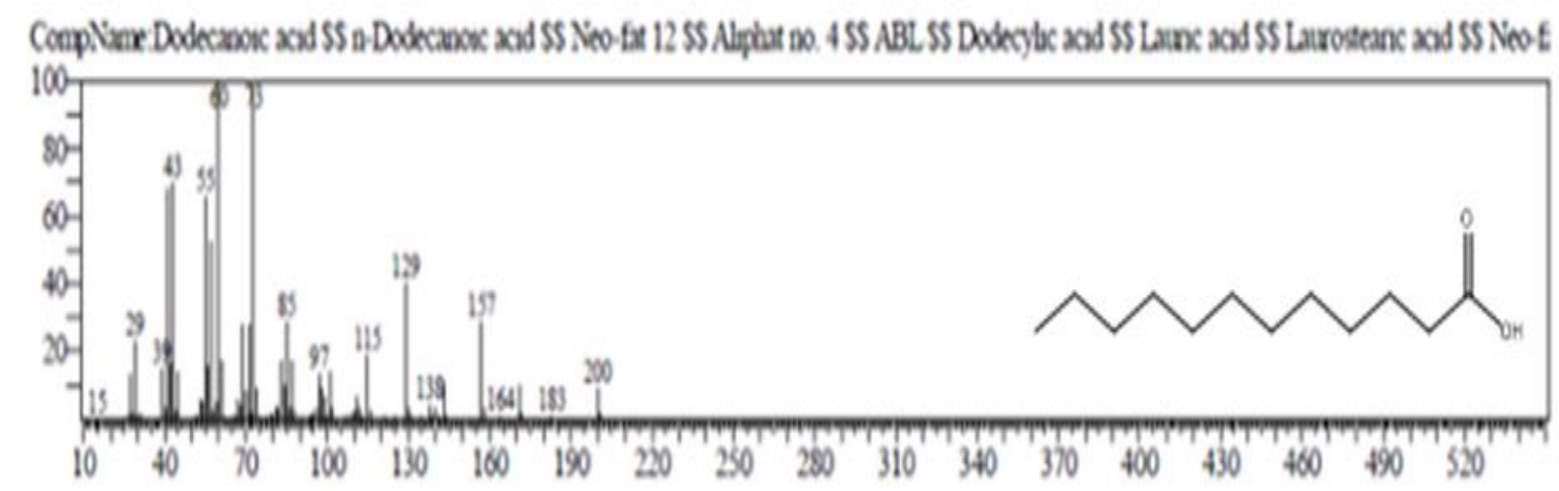

Figure 13 Mass spectrum of suggested structure of Compound 2 by NIST library.

The chemical structure of Compound 2 has functional group (O-H stretch) which appeared at $3341 \mathrm{~cm}^{-1}$ as illustrated in the IR spectrum (Figure 14). An absorption bands of C-H was observed at $2974 \mathrm{~cm}^{-1}$ which indicated the presence of methyl carbon in the chemical structure. A signal was observed at $1653 \mathrm{~cm}^{-1}$ which indicated the presence of $\mathrm{C}=0$ bond. At $1384 \mathrm{~cm}^{-1}$ a signal was observed which matched the double bonds of $\mathrm{C}=\mathrm{C}$ in the suggested structure. Single bond C$\mathrm{C}$ stretching was observed at $878 \mathrm{~cm}^{-1}$ in the IR spectrum of Compound 2.

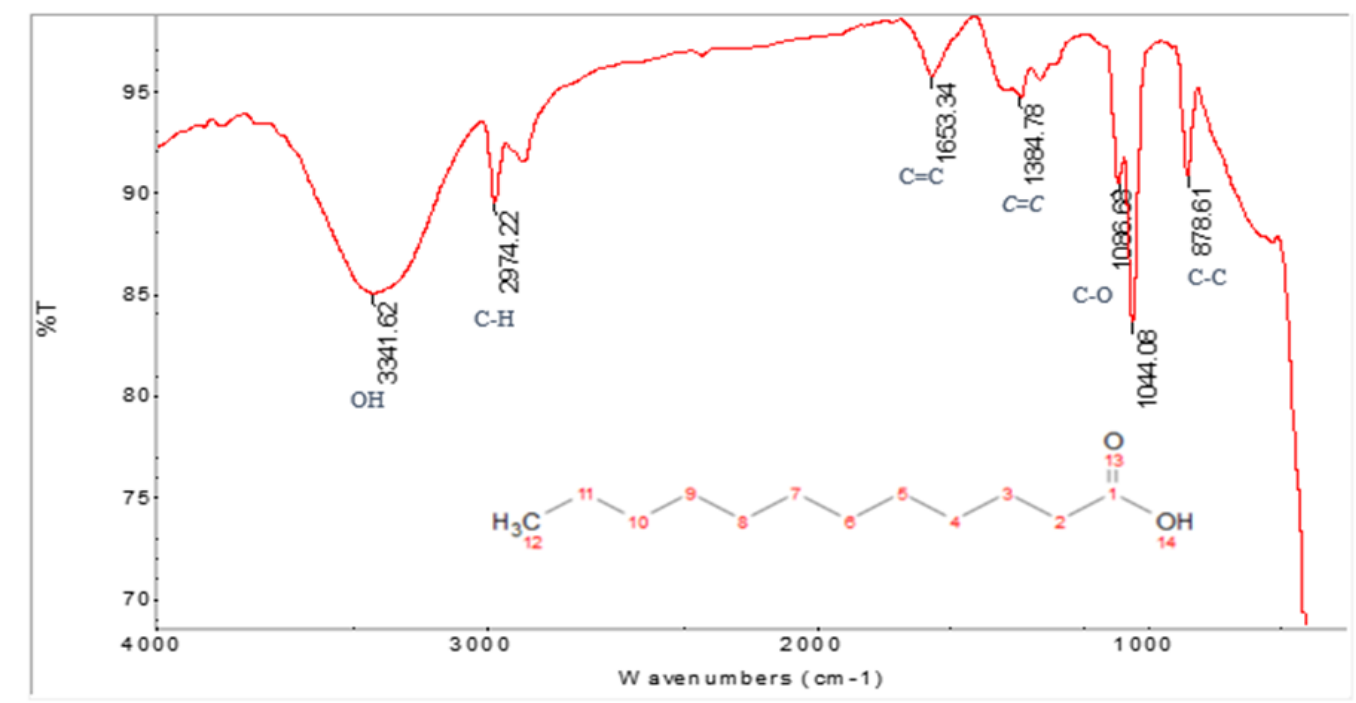

Figure 14 IR Spectrum of Compound 2

NMR analysis was further performed for the elucidation of the chemical structure of Compound 2. The results are shown in Figure 15 and Figure 16 ( ${ }^{1} \mathrm{H}$-NMR), Figure 17 and Figure $18\left({ }^{13} \mathrm{C}\right.$-NMR). Based on the table of ${ }^{1} \mathrm{H}$-NMR characteristics 
absorption and ${ }^{1} \mathrm{H}$-NMR peaks splitting pattern as reported in Organic Chemistry by Silverstein (2005), the proton signals were all integrated and were assigned to every proton NMR of Compound 2 as the proposed chemical structure.

The ${ }^{1} \mathrm{H}-\mathrm{NMR}$ spectrum of Compound 2 exhibited 13 proton resonates. A singlet proton signal was observed at $\delta 9.47$ $(1 \mathrm{H}, \mathrm{s})$ indicating the presence of an $\mathrm{OH}$ group (hydroxyl) of the structure. A doublet proton signal was observed at $\delta$ $2.28, \delta 1.63, \delta 1.33, \delta 1.32, \delta 1.31, \delta 1.31, \delta 1.31, \delta 1.31, \delta 1.30$ and $\delta 1.37$, respectively. Indicating the presence of a methylene group of the long chain of Compound 2 and was assigned to $\mathrm{H}-2, \mathrm{H}-3, \mathrm{H}-4, \mathrm{H}-5, \mathrm{H}-6, \mathrm{H}-7, \mathrm{H}-8, \mathrm{H}-9, \mathrm{H}-10$, and $\mathrm{H}-11$. A multiplet proton signal was observed at $\delta 0.99(3 \mathrm{H}, \mathrm{m})$ which correspond with a methyl group and was assigned to $\mathrm{H}-12$.

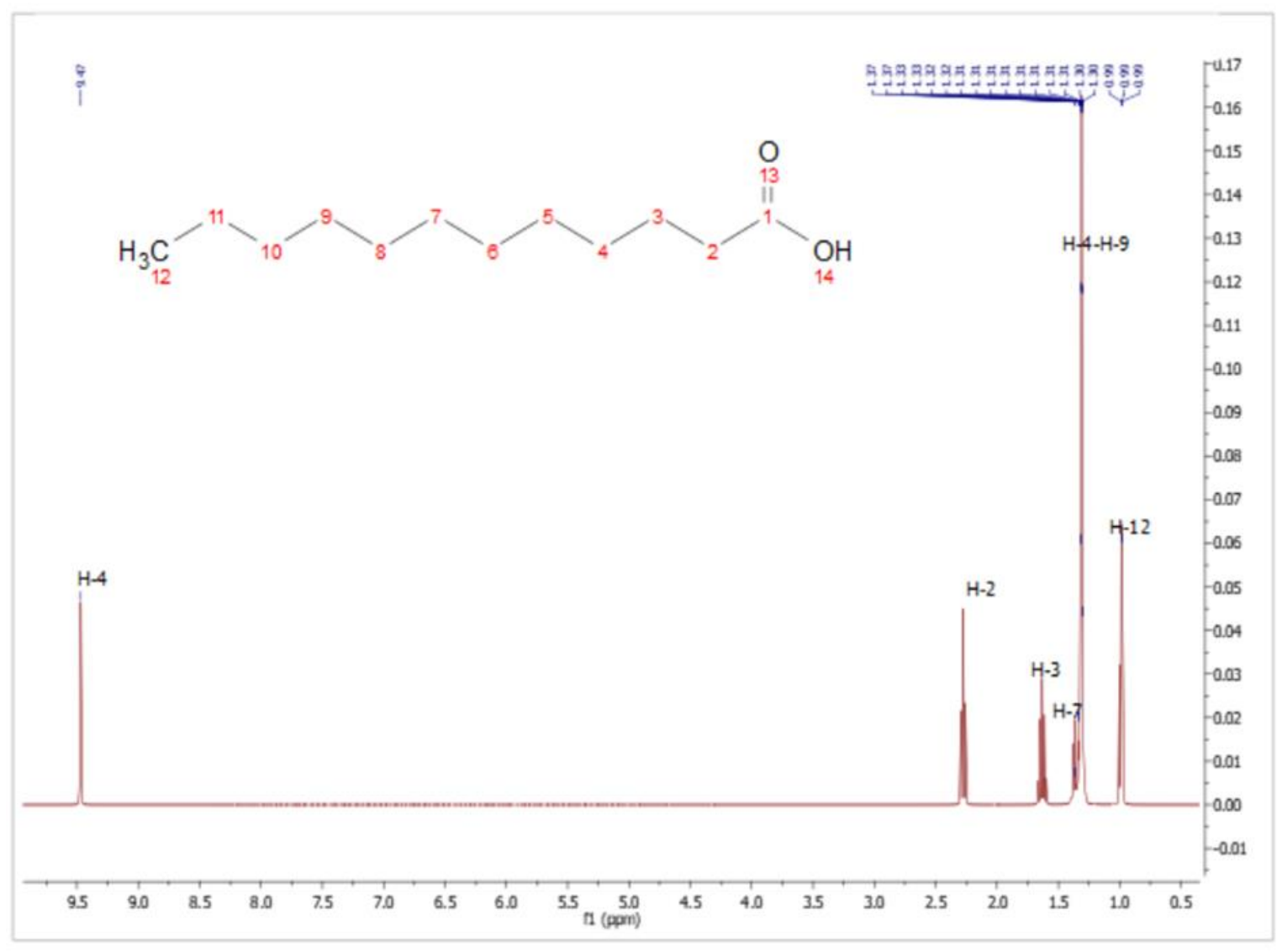

Figure $15{ }^{1} \mathrm{H}-\mathrm{NMR}$ spectrum of Compound 2 from 0.5 to 9.5 (500 MHz, $\mathrm{CDCl}_{3}$ ) 


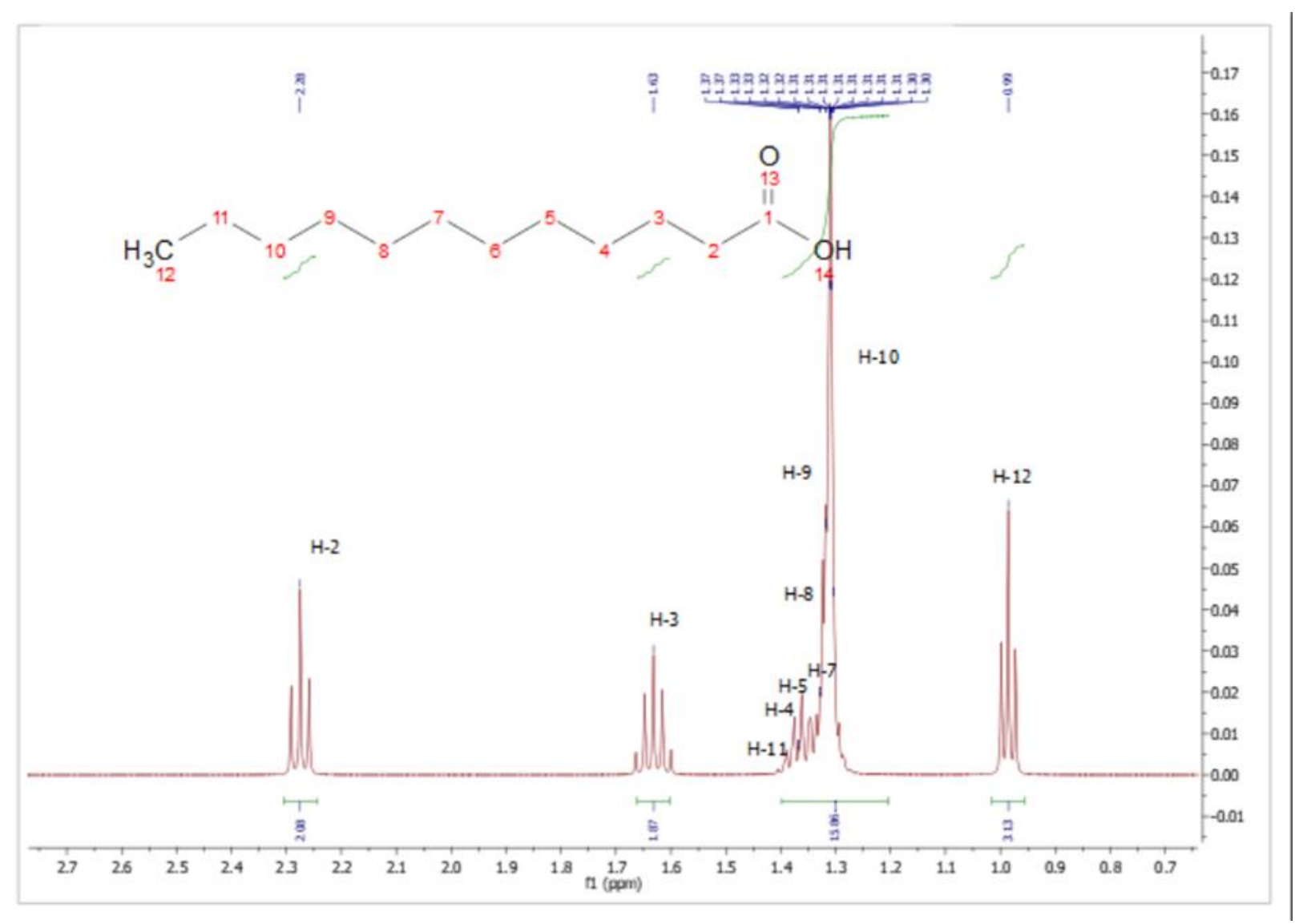

Figure 16 1H-NMR spectrum of Compound 2 from 0.7 to 2.7 (500 MHz, CDCl3)

From the result of the 13C-NMR spectrum of Compound 2 every carbon NMR signal that was observed was assign to the proposed chemical structure of Compound 2 which is based on the table of 13C-NMR characteristics absorption reported in Organic Chemistry Silverstein (2005).

A total of 12 carbon resonates were observed in the 13C-NMR spectrum of Compound 2. At the downfield region signals were observed at $\delta 177.13$ and was assigned to C-1. A signal was observed at unfiled region at $\delta 34.35, \delta 24.81, \delta 28.93$, $\delta 28.96, \delta 28.96, \delta 28.96, \delta 28.96, \delta 29.06, \delta 31.65, \delta 22.94$ and $\delta 14.02$ and was assigned to C-2, C-3, C-4, C-5, C-6, C-7, C-8, C-9, C-10, C-11and C-12, respectively.

Chemical shift of every proton and carbon NMR for Compound 2 is shown in Table 12 and Table 13 and comparison was made with NMR data of similar compound reported by Yamashita et al., (2015) and Zhu (2014). 
Umaru et al. / GSC Biological and Pharmaceutical Sciences, 2020, 10(02), 070-098

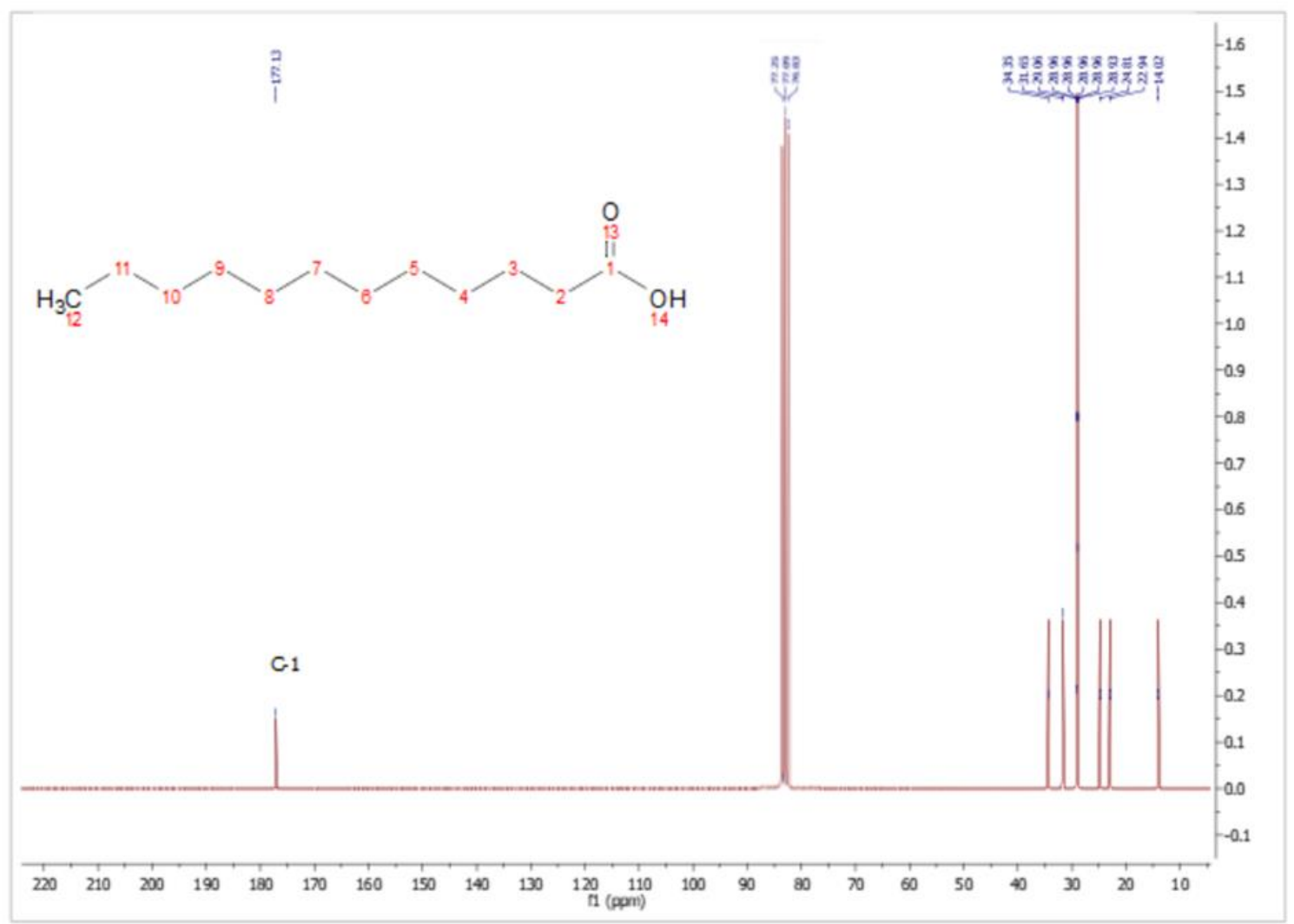

Figure 17 13C-NMR spectrum of Compound 2 from 10 to 220 (125 MHz, CDCl3) 


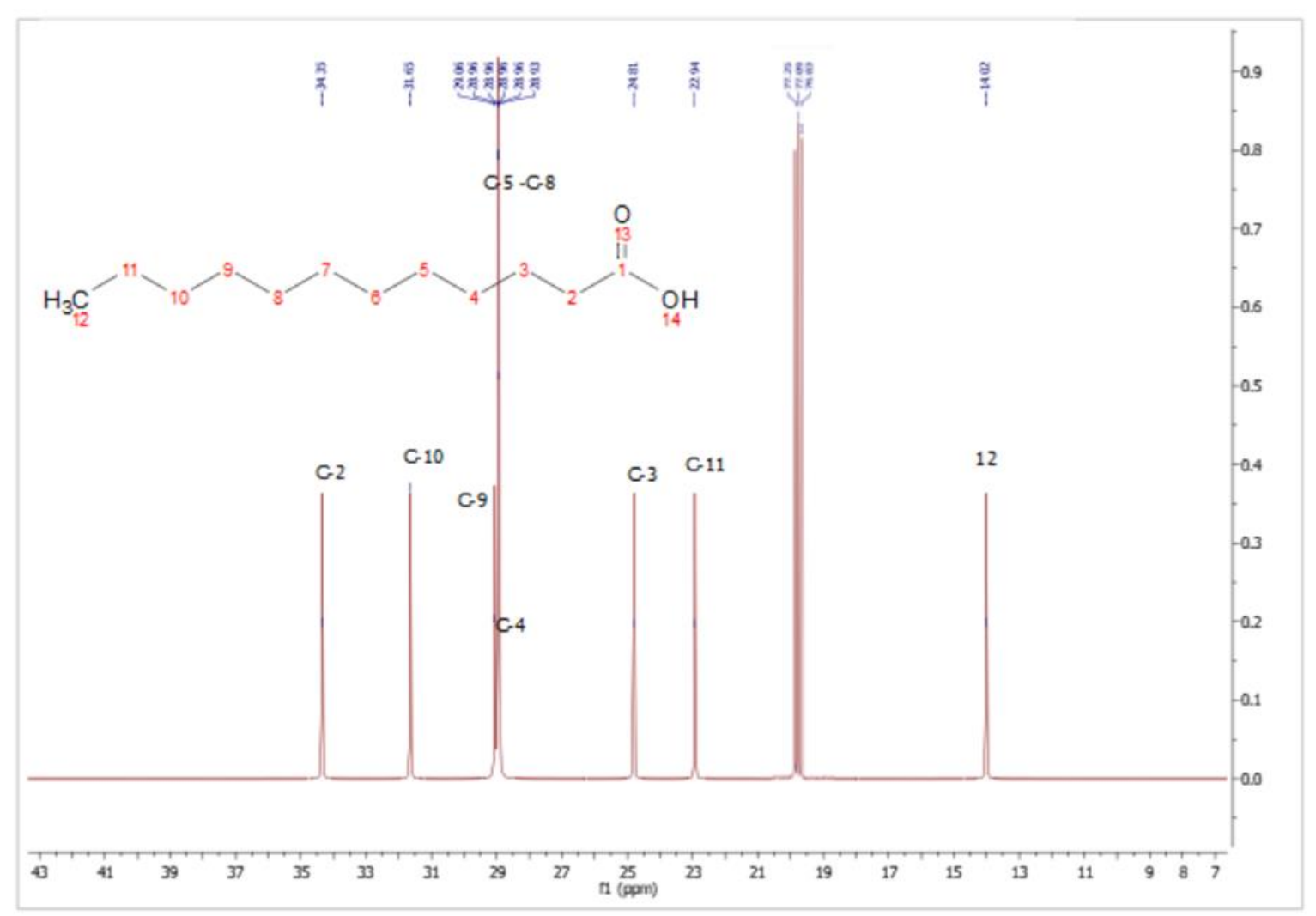

Figure 18 13C-NMR spectrum of Compound 2 from 13 to 35 (125 MHz, CDCl3)

Table 11 Proton NMR signal of Compound 2 and that reported by Yamashita et al., (2015).

\begin{tabular}{llll}
\hline $\begin{array}{l}\text { Proton } \\
\text { assigned to } \\
\text { Compound 2 }\end{array}$ & $\begin{array}{l}\text { Proton chemical } \\
\text { shift } \\
\text { Compound 2 }\end{array}$ & $\begin{array}{l}\text { Proton assigned } \\
\text { of } \\
\text { dodecanoic acid } \begin{array}{c}\text { to } \\
\text { Yamashita et al., (2015) }\end{array}\end{array}$ & $\begin{array}{l}\text { Proton chemical shift (ppm) of } \\
\text { dodecanoic acid (Yamashita } \text { et } \\
\text { al., 2015) }\end{array}$ \\
\hline $\mathrm{H}-2$ & $2.28(2 \mathrm{H}, \mathrm{m})$ & $\mathrm{H}-2$ & $2.30(2 \mathrm{H}, \mathrm{m})$ \\
$\mathrm{H}-3$ & $1.63(2 \mathrm{H}, \mathrm{m})$ & $\mathrm{H}-3$ & $1.52(2 \mathrm{H}, \mathrm{m})$ \\
$\mathrm{H}-4$ & $1.33(2 \mathrm{H}, \mathrm{m})$ & $\mathrm{H}-4$ & $1.29(2 \mathrm{H}, \mathrm{m})$ \\
$\mathrm{H}-5$ & $1.32(2 \mathrm{H}, \mathrm{m})$ & $\mathrm{H}-5$ & $1.26(2 \mathrm{H}, \mathrm{m})$ \\
$\mathrm{H}-6$ & $1.31(2 \mathrm{H}, \mathrm{m})$ & $\mathrm{H}-6$ & $1.26(2 \mathrm{H}, \mathrm{m})$ \\
$\mathrm{H}-7$ & $1.31(2 \mathrm{H}, \mathrm{m})$ & $\mathrm{H}-7$ & $1.26(2 \mathrm{H}, \mathrm{m})$ \\
$\mathrm{H}-8$ & $1.31(2 \mathrm{H}, \mathrm{m})$ & $\mathrm{H}-8$ & $1.26(2 \mathrm{H}, \mathrm{m})$ \\
$\mathrm{H}-9$ & $1.31(2 \mathrm{H}, \mathrm{m})$ & $\mathrm{H}-9$ & $1.29(2 \mathrm{H}, \mathrm{m})$ \\
$\mathrm{H}-10$ & $1.30(2 \mathrm{H}, \mathrm{m})$ & $\mathrm{H}-10$ & $1.29(2 \mathrm{H}, \mathrm{m})$ \\
$\mathrm{H}-11$ & $1.37(2 \mathrm{H}, \mathrm{m})$ & $\mathrm{H}-11$ & $1.312 \mathrm{H}, \mathrm{m})$ \\
$\mathrm{H}-12$ & $0.99(3 \mathrm{H}, \mathrm{t}, \mathrm{J}=56)$ & $\mathrm{H}-12$ & $0.88(3 \mathrm{H}, \mathrm{t}, \mathrm{J}=57)$ \\
$\mathrm{H}-14$ & $9.47(1 \mathrm{H}, \mathrm{s})$ & $\mathrm{H}-14$ & - \\
\hline
\end{tabular}


Table 12 Carbon NMR signal of Compound 2 and that reported by Yamashita et al. (2015).

\begin{tabular}{|c|c|c|c|}
\hline $\begin{array}{l}\text { Carbon } \\
\text { assigned to } \\
\text { Compound } 2\end{array}$ & $\begin{array}{l}\text { Carbon chemical } \\
\text { shift (ppm) of } \\
\text { Compound } 2\end{array}$ & $\begin{array}{l}\text { Carbon assigned to } \\
\text { dodecanoic } \quad \text { acid } \\
\text { (Yamashita et al., 2015) }\end{array}$ & $\begin{array}{l}\text { Carbon chemical shift (ppm) } \\
\text { of dodecanoic acid } \\
\text { (Yamashita et al., } 2015\end{array}$ \\
\hline C-1 & 177.13 & C-1 & 178.4 \\
\hline C-2 & 34.35 & $\mathrm{C}-2$ & 34.0 \\
\hline$C-3$ & 24.81 & C-3 & 24.7 \\
\hline$C-4$ & 28.93 & $C-4$ & 29.0 \\
\hline C-5 & 28.96 & $C-5$ & 29.3 \\
\hline C-6 & 28.96 & C-6 & 29.6 \\
\hline C-7 & 28.96 & $C-7$ & 29.6 \\
\hline C-8 & 28.96 & C-8 & 29.6 \\
\hline C-9 & 29.06 & C-9 & 29.4 \\
\hline$C-10$ & 31.65 & C-10 & 31.9 \\
\hline C-11 & 22.94 & C-11 & 22.7 \\
\hline$C-12$ & 14.02 & C-12 & 14.1 \\
\hline
\end{tabular}

From the data obtained, the GC spectrum of Compound 2 gave a similarity index of $96.5 \%$ with the mass spectrum of the proposed structure by the NIST library, which matched the characteristic of dodecanoic acid (2) with chemical formula $\mathrm{C}_{12} \mathrm{H}_{24} \mathrm{O}_{2}$. The melting point of Compound 2 is $44.6^{\circ} \mathrm{C}$. The proton and carbon NMR data of Compound 2 were mostly identical to match the NMR signal of dodecanoic acid (2) as reported by Zhu (2014).

Based on mass spectrum, IR, ${ }^{1} \mathrm{H}-\mathrm{NMR}$ and ${ }^{13} \mathrm{C}$-NMR data and comparison with published literature (Yamashita et al., 2015; Zhu, 2014) Compound 2 was identified as dodecanoic acid (2).

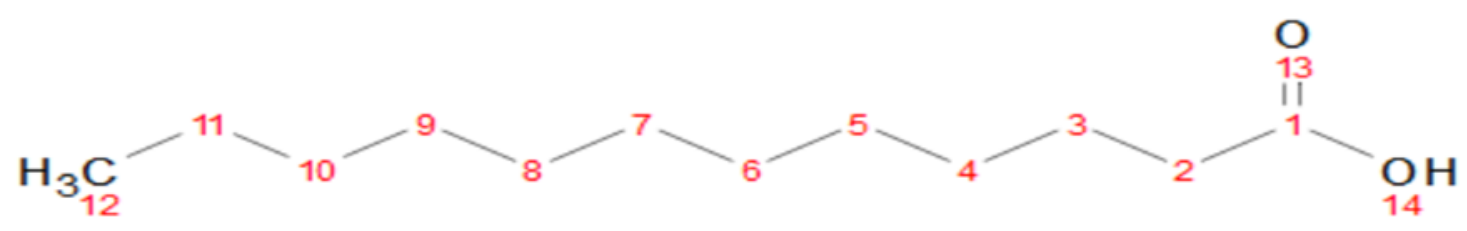

Dodecanoic acid (1) is a compound containing a carboxylic group attached to the terminal end of carbon one in the structure. The acid was report to have showed virucidal effects on enveloped RNA and DNA viruses. It was also observed to have inactivate bacteria, yeast, fungi, and enveloped viruses. It is also an active anti-microbial, that is alpha- and betaMG. Also, it is mentioned that the anti-microbial effects of the dodecanoic acid are additive and total concentration is critical for inactivating viruses (Yamashita et al., 2015). Dodecanoic acid has greater anti-viral properties and many of the pathogenic organisms reported to be inactivated by these antimicrobial compound. It is known to be responsible for opportunistic infections in HIV-positive individuals. It can kill harmful pathogens like bacteria, viruses and fungi. This important compound can be beneficial to infants in reducing the cancer risk and future heart disease (Niknamian and Niknamian, 2015).

In a study reported by Rayan and McDonnell (2014), that dietary supplementation of dodecanoic acid in maternal mice enhances resistance to giardia duodenalis infection in suckling Neonatal pups.

Yamashita reported the identification of self-growth-inhibiting compounds of dodecanoic acid from Helicobacter pylori (Yamashita et al., 2015). 


\subsection{Cytotoxicity, Antioxidant and Biological activity of Hornstedtia scyphifera var leaf solvent Crude extract}

\subsubsection{Cytotoxicity of Hornstedtia scyphifera var leaf extract using Brine Shrimp (Artemia salina)}

Result in Table 13 shows the leaf crude extract of hexane, dichloromethane. Chloroform, ethyl acetate and methanol fraction. Highest brine shrimp lethality was observed in methanol crude and hexane crude extract with $\mathrm{LC}_{50}$ value of $34.059 \mu \mathrm{g} / \mathrm{mL}, 35.462$, respectively. Ethyl acetate crude extract exhibited the lowest activity with LC 50 value 62.220 $\mu \mathrm{g} / \mathrm{mL}$ when compared to the test control thymol of $1.16 \mu \mathrm{g} / \mathrm{mL}$. There was an observed concentration dependent increment in mortality rate of the brine shrimp. The isolated compound as shown in table 14, dodecanoic acid exhibited higher toxicity of $\mathrm{LC}_{50}$ of $46.23 \mu \mathrm{g} / \mathrm{mL}$ and Quercetin of $\mathrm{LC}_{50} 56.66 \mu \mathrm{g} / \mathrm{mL}$.

In toxicity evolution of plant extracts by brine shrimp lethality bioassay, LC 50 values lower than $1000 \mu \mathrm{g} / \mathrm{mL}$ are considered active (Umaru et al., 2018). This has been well utilized for screening and fractionation of physiologically active plant extracts and has also been demonstrated to correlates reasonably well with cytotoxic and other biological properties (Isaac et al., 2018). Brine shrimp bioassay has been established as safe, practical and economical method for determination of bioactivities of synthetic compounds (Almeida et al., 2002). It has established a significant correlation with in-vitro growth inhibition of human solid tumor cell where it shows the value of this bioassay as a pre-screening tool for antitumor drug research (Anderson et al., 1991). Which support the results obtained from crude and isolated compound of the leaf extract of Hornstedtia scyphifera var as an agent to be considered.

Table 13 Average death of brine shrimp (Artemia salina) at different concentrations of the Hornstedtia scyphifera var leaf extract

\begin{tabular}{|c|c|c|c|c|c|c|}
\hline \multicolumn{7}{|c|}{ Solvent system } \\
\hline \multirow{8}{*}{ Leaf } & & 5 & 10 & 50 & 100 & \\
\hline & -ve Control & 0 & 0 & 0 & 0 & 0 \\
\hline & +ve Thymol & $5 \pm 0.55$ & $7 \pm 0.55$ & $10 \pm 0.55$ & $10 \pm 0.55$ & 1.16 \\
\hline & Hexane & $3 \pm 0.57$ & $4 \pm 0.55$ & $5 \pm 0.55$ & $7 \pm 0.55$ & 35.462 \\
\hline & Dichloromethane & $3 \pm 0.57$ & $3 \pm 0.57$ & $4 \pm 0.57$ & $5 \pm 0.00$ & 47.722 \\
\hline & Chloroform & $3 \pm 0.56$ & $3 \pm 0.56$ & $4 \pm 0.56$ & $5 \pm 0.10$ & 46.924 \\
\hline & Ethyl acetate & $2 \pm 0.55$ & $3 \pm 0.55$ & $4 \pm 0.55$ & $4 \pm 0.00$ & 62.220 \\
\hline & Methanol & $3 \pm 0.54$ & $4 \pm 0.54$ & $4 \pm 0.54$ & $7 \pm 0.54$ & 34.059 \\
\hline
\end{tabular}

Table 14 Average death of brine shrimp (Artemia salina) at different concentration of isolated compounds

\begin{tabular}{|c|c|c|c|c|c|c|c|}
\hline \multirow{2}{*}{$\begin{array}{l}\text { Solvent } \\
\text { system }\end{array}$} & \multicolumn{6}{|c|}{$\begin{array}{l}\text { Average death of Artemia salina } \\
\text { Concentration }(\mu \mathrm{g} / \mathrm{mL})\end{array}$} & \multirow[t]{2}{*}{$\begin{array}{l}\mathrm{LC}_{50} \\
(\mu \mathrm{g} / \mathrm{mL})\end{array}$} \\
\hline & 1 & 10 & 25 & 50 & 100 & 500 & \\
\hline -ve Control (DMSO) & 0 & 0 & 0 & 0 & 0 & 0 & - \\
\hline +ve Thymol & $5.00 \pm 0.57$ & $7.00 \pm 0.58$ & $10.00 \pm 0.00$ & $10.00 \pm 0.00$ & $10.00 \pm 0.00$ & $10.00 \pm 0.00$ & 1.16 \\
\hline Quercetin & $1.00 \pm 0.00$ & $3.57 \pm 0.58$ & $3.10 \pm 0.00$ & $3.31 \pm 0.58$ & $4.23 \pm 0.58$ & $4.57 \pm 0.58$ & 56.66 \\
\hline Dodecanoic acid & $2.00 \pm 0.13$ & $3.00 \pm 0.12$ & $3.33 \pm 0.55$ & $4.18 \pm 0.57$ & $4.54 \pm 1.15$ & $5.13 \pm 0.58$ & 46.23 \\
\hline
\end{tabular}




\subsubsection{Antioxidant Activity of Hornstedtia scyphifera var leaf crude extract}

Many medicinal plants as well as the pure bioactive isolates have demonstrated tremendous beneficial therapeutic potentials, and many herbs were reported to contain antioxidant properties, and most of these activities are largely attributed to the phytochemicals (Aqil et al., 2006). Antioxidants are substances that possess free radical chain reaction breaking properties (Isaac et al., 2018), antioxidant activity is a fundamental important property for life (Velioglu et al., 1998) and has been shown to reduce oxidative stress-induced tissue injury (Pourmorad et al., 2006).

Free radical scavenging activities of leaf Hornstedtia scyphifera from different solvent systems of varying polarity as while as the isolated compounds were evaluated using DPPH a stable free radical method that is sensitive in determining the antioxidant activity of plant extracts and vegetables. It has been reported that natural antioxidant presents in plants scavenge harmful free radicals from human body and exert their mode of action by suppressing the formation of reactive oxygen species either by inhibition of enzyme or by chelating trace elements (Asok Kumar et al., 2009).

The antioxidant effect of Hornstedtia scyphifera is shown in Table 15 and Figure 19 for crude extract and Table 16 and Figure 20 for isolated compounds. The results of the study showed that methanol and chloroform fractions of the leaf extract exhibit strong antioxidant activity with $\mathrm{IC}_{50}$ values of $34.43 \pm 0.110 \mu \mathrm{g} / \mathrm{mL}$ and $34.46 \pm 0.32 \mu \mathrm{g} / \mathrm{mL}$, respectively. The strong antioxidant activity exhibited by the methanol extract in this study is congruent to the work of Mariya and Reena (2007) in which they reported that methanolic extract was found to be most effective antioxidant property. It was observed also that hexane and dichloromethane fractions exhibited weak antioxidant activity with $\mathrm{IC}_{50}$ values $63.4 \pm 0.11$ and $51.91 \pm 0.921$ when compared to the standard ascorbic acid of $17.27 \pm 10.16 \mu \mathrm{g} / \mathrm{mL}$.

Table 16 and Figure 19 shows the dodecanoic acid to have higher antioxidant potential of 30.63 and lower was observed with dodecanoic acid of 39.47 when compared to the control ascorbic acid of Figure 20.

Table 15 IC $_{50}$ values of leaves crude extract of Hornstedtia scyphifera

\begin{tabular}{llll}
\hline & Crude extract & IC $_{\mathbf{5 0}}(\boldsymbol{\mu g} / \mathbf{m L})$ & R2 \\
\hline \multirow{4}{*}{ Leaves } & Control & $17.27 .4 \pm 0.16$ & 0.9937 \\
& Hexane & $63.4 \pm 0.11$ & 0.9824 \\
& Dichloromethane & $51.91 \pm 0.921$ & 0.9362 \\
& Chloroform & $34.46 \pm 0.32$ & 0.9886 \\
& Ethyl acetate & $44.26 \pm 0.26$ & 0.9949 \\
& Methanol & $35.33 \pm 0.210$ & 0.9838 \\
\hline
\end{tabular}

Table 16 DPPH IC50 ( $\mu \mathrm{g} / \mathrm{mL})$ Value of Isolated Compound

\begin{tabular}{llc}
\hline Standard and compound & R2 and & IC50 $(\boldsymbol{\mu g} / \mathbf{m L})$ \\
\hline \multirow{2}{*}{ Standard Vitamin C } & R2 & IC50 $(\mu \mathrm{g} / \mathrm{mL})$ \\
Quercetin & 0.9657 & 17.27 \\
Dodecanoic acid & 0.9070 & 30.63 \\
\multicolumn{2}{c}{$\mathrm{IC}_{50}=$ Half maximal inhibitory concentration }
\end{tabular}

\subsubsection{Antibacterial Activity of Leaves extract of Hornstedtia scyphifera}

Over the years, there has been a tremendous increase on the report of antimicrobial properties of medicinal plants by researchers worldwide and this has contributed enormously to the understanding and discovery of natural agents that could be effective in combating microorganism in human health delivery. Table 17 and Table 18 show the mean values of the zone of growth inhibition of leaf extract and isolated compound of Hornstedtia scyphifera against bacterial strains in mm compared to tetracycline. 


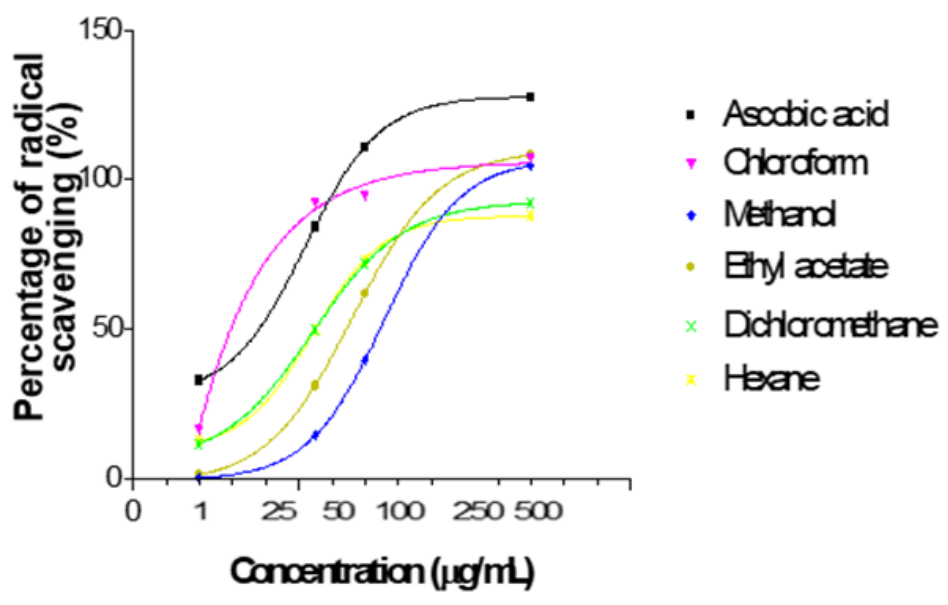

Figure 19 Radical scavenging activities of leaves extract in different solvents at absorbance of $517 \mathrm{~nm}$.

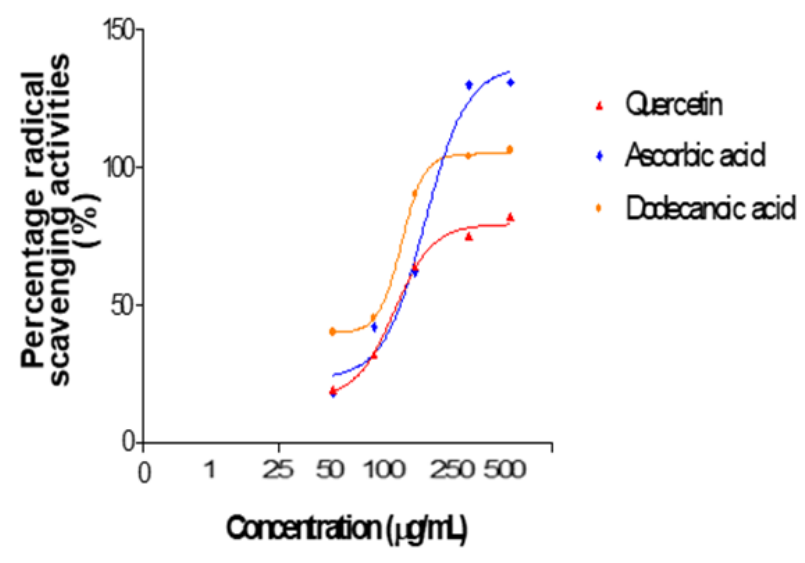

Figure 18 Radical scavenging activities of Isolated pure compounds at absorbance of $517 \mathrm{~nm}$.

In this study, the leaf extracts and the isolated compounds quercetin and dodecanoic acid of Hornstedtia scyphifera showed significant bactericidal effects against the test bacterial strains; Escherichia coli (E. coli), Salmonella typhi (S. typhi), Klebsiella pneumonia (K. pneumonia) and Staphylococcus aureus (S. aureus), as shown in Table 17 and Table 18.

There was an observed significant activity of the crude extract at $500 \mu \mathrm{g} / \mathrm{mL}$ in all the extracts against the selected pathogen with zone of growth inhibition ranging from $07.70 \pm 27.30 \mathrm{~mm}$ to $19.30 \pm 0.10 \mathrm{~mm}$. The activity was observed in Salmonella typhi ranged from $7.87 \pm 0.06 \mathrm{~mm}$ in ethyl acetate extract to $17.97 \pm 0.06 \mathrm{~mm}$ in methanol extract. The activity against $E$. coli was observed in all the extract which ranged from $7.47 \pm 0.15 \mathrm{~mm}$ in chloroform extract to 19.73 $\pm 0.06 \mathrm{~mm}$ in hexane extract, as compared to standard drug tetracycline with zone of growth inhibition of $19.77 \pm 0.38$ $\mathrm{mm}$.

The activity against $S$. aureus was observed in all the extract range from $9.67 \pm 0.06 \mathrm{~mm}$ methanol to $18.06 \pm 0.06 \mathrm{~mm}$ methanol at $500 \mu \mathrm{g} / \mathrm{mL}$. The activity of leaf extract of Hornstedtia scyphifera on this pathogen K. pneumonia range from $10.0 \pm 0.00 \mathrm{~mm}$ ethyl acetate to $16.10 \pm 0.10 \mathrm{~mm}$ ethyl acetate. However higher inhibition was observed with ethyl acetate and methanol crude on Escherichia coli with inhibition value of $20.80 \pm 0.10 \mathrm{~mm}$ and $20.80 \pm 0.10 \mathrm{~mm}$, respectively. Lower inhibition was generally observed with hexane crude extract as shown in the Table 17. 
Table 17 Mean values of the zone of growth inhibition of extract of Leaves extract of Hornstedtia scyphifera of different concentration.

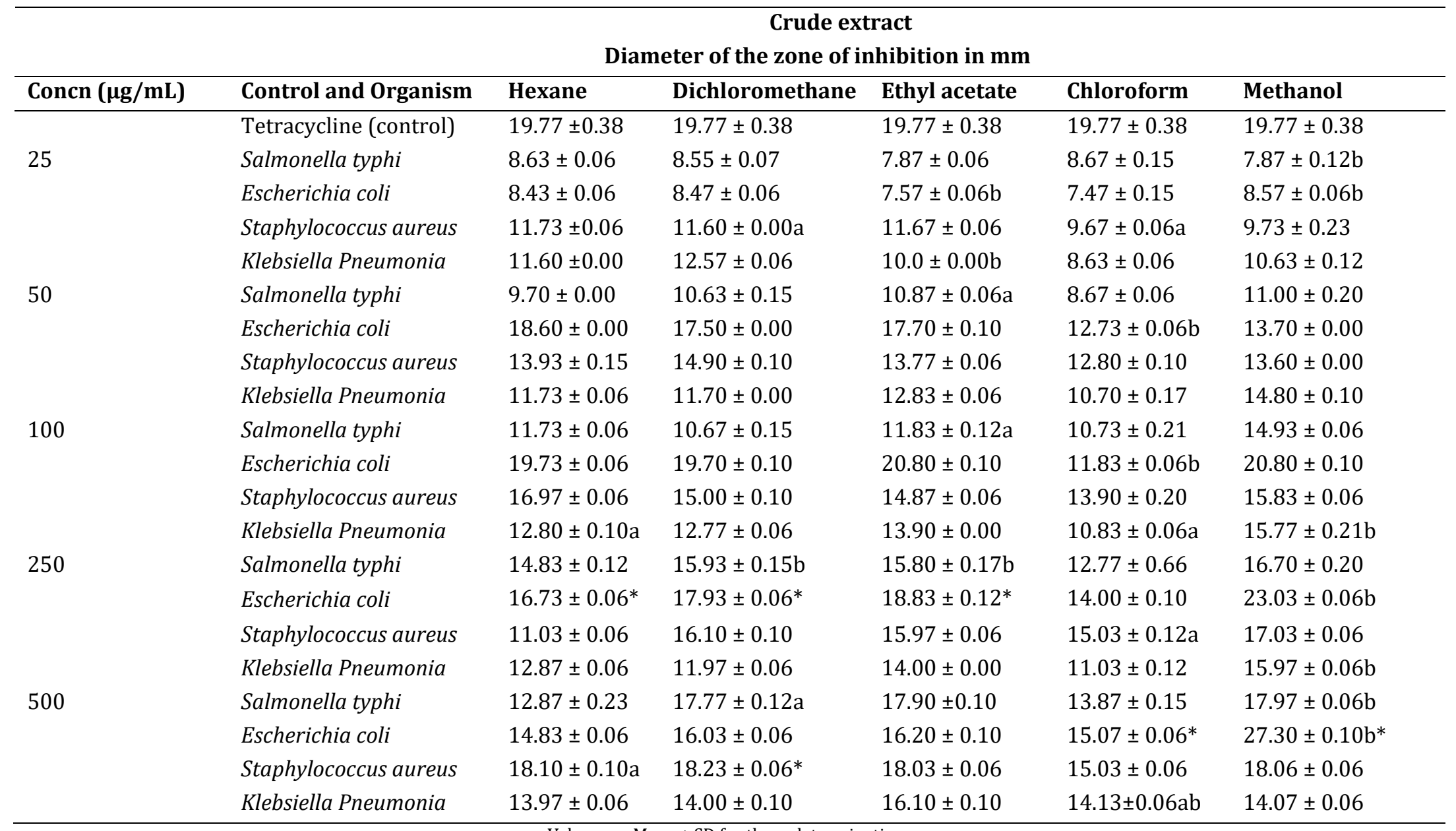

*Significantly $(\mathrm{p}<0.05)$ higher compared to different plant part at the same concentration in each column Concentration of standard is $30 \mu \mathrm{g} / \mathrm{mL}$ of tetracycline 
The finding is congruent to studies reported on the effects of solvent medicinal plants extract on S. typhi, E. coli, S. aureus and K. pneumonia by some authors (Daljit et al., 1999; Prashanth et al., 2006; Apu et al., 2010; Nayan et al., 2011).

Table 18 showed quercetin to have higher growth inhibition value of $20.7 \pm 0.04 \mathrm{~mm}$ on Klebsiella pneumonia, dodecanoic acid showed growth inhibition of $18.00 \pm 0.0 \mathrm{~mm}$ at the same concentration $(100 \mu \mathrm{g} / \mathrm{mL}) \mathrm{on}$ Salmonella typhi. Lower inhibition was observed at $25 \mu \mathrm{g} / \mathrm{mL}$ on Salmonella typhi of $9.20 \pm 0.02 \mathrm{~mm}$ and $9.00 \pm 0.00 \mathrm{~mm}$, respectively when compared to the control tetracycline of $19.8 \pm 2.20 \mathrm{~mm}$.

However, at lower concentrations of the crude extract, activity was observed but they are not significant as compared to the standard drug as while as to the standard inhibition where inhibition $<9$ is considered inactive reported by Jan Hudzicki, (2009).

Table 18 Antibacterial activity of isolated pure compounds

\begin{tabular}{lllll}
\hline $\begin{array}{l}\text { Concentration } \\
(\boldsymbol{\mu g} / \mathbf{m L})\end{array}$ & Bacteria & $\begin{array}{l}\text { Control } \\
\text { Tetracycline } \mathbf{( 3 0 \mu g )}\end{array}$ & Quercetin & Dodecanoic acid \\
\hline \multirow{2}{*}{$25 \mu \mathrm{g} / \mathrm{mL}$} & Escherichia coli & $17.30 \pm 1.6$ & $11.4 \pm 0.05$ & $12.6 \pm 0.43$ \\
& Klebsiella pneumonia, $S T$ & $19.80 \pm 2.2$ & $11.7 \pm 0.16$ & $13.3 \pm 0.16$ \\
& Salmonella typhi & $25.1 \pm 3.40$ & $9.20 \pm 0.02$ & $9.00 \pm 0.00$ \\
$50 \mu \mathrm{g} / \mathrm{mL}$ & Escherichia coli & $17.3 \pm 0.30$ & $15.7 \pm 0.04$ & $12.7 \pm 0.16$ \\
& Klebsiella pneumonia, $S T$ & $19.8 \pm 2.20$ & $16.2 \pm 0.02$ & $17.3 \pm 0.16^{*}$ \\
& Salmonella typhi & $25.1 \pm 3.40$ & $16.2 \pm 0.02$ & $14.3 \pm 0.16$ \\
$100 \mu \mathrm{g} / \mathrm{mL}$ & Escherichia coli & $17.32 \pm 1.6$ & $16.9 \pm 0.05$ & $12.9 \pm 0.28^{*}$ \\
& Klebsiella pneumonia, $S T$ & $19.8 \pm 2.20$ & $20.7 \pm 0.04^{*}$ & $15.5 \pm 0.14$ \\
& Salmonella typhi & $25.1 \pm 3.40$ & $15.7 \pm 0.04$ & $18.00 \pm 0.0^{*}$ \\
\hline
\end{tabular}

\section{Conclusion}

In this study, we extracted, isolated and characterized two pure compound quercetin and dodecanoic acid from Hornstedtia scyphifera var leaf, a series of biological activity was experimented, demonstrating the necessity of the crude extract as an agent for proper function as an antioxidant and antibacterial potential. These results help to explain the high sequence of medicinal activity deposited and observed at this position in all the solvent extract and the isolated pure compounds. We subsequently found that the crude extract, because of the composition of the phytochemical deposit such as quercetin and dodecanoic acid, the plant extract and its isolate could be used as an agent in pharmaceutical industry. To the best of our knowledge this known compound was first isolated in this plant Hornstedtia scyphifera var leaf.

\section{Compliance with ethical standards}

\section{Acknowledgments}

The authors wish to acknowledge Federal Unversity wukari for their financial support and research grant 07(ZRC05/1238/2015(2) provided by Universiti Malaysia Sarawak which has resulted to this article.

\section{Disclosure of conflict of interest}

The authors declare no competing of interest.

\section{References}

[1] Dahiru D, Mamman DN and Wakawa HY. (2010). Ziziphus mauritiana fruit extract inhibits carbon tetrachloride-induced hepatotoxicity in male rats. Pakistan Journal of Nutrition, 9(10), 990-993. 
[2] Fatahi M, Rashidabady T and Fetahi-Hassanabad Z. (2003). Effects of Crocus sativa petal extract on rat blood pressure on response induced by electrical field stimulation in the rat isolated vas deferner and guinea pig's ileum. Journal of Ethno pharmacology, 84, 119-203.

[3] Jani NA, Ibrahim N, Hashim ST and Mohd H. (2016). Antimicrobial and Antioxidant activities of Hornstedtia leonurus Retz. Extracts. Journal of Science and Technology, 1-9.

[4] Hashim SE, Sirat HM and Yen KH. (2014). Chemical Compositions and Antimicrobial Activity of the Essential Oils of Hornstedtia havilandii (Zingiberaceae). Natural Product Communications, 9(1), 119-120.

[5] Holtum RE. (1950). The Zingiberaceae of the Malay Peninsula, Volume 13, Garden's Bulletin Singapore, Singapore.

[6] Fasihuddin BA, Sallehuddin NKNM and Assim Z. (2010). Chemical constituents and antiviral study of Goniothalamus velutinus. Malaysian Journal of Fundamental and Applied Sciences, 6(1), 73-76.

[7] Isaac JU, Fasihuddin, AB, Zaini, BA and Hauwa, AU. (2018). Antibacterial and cytotoxic actions of chloroform crude extract of Leptadenia hastata (pers) Decnee. Clin Med Biochemistry, 4, 1-4.

[8] Firdous AM, Fayaz AL and Mushtaq AS. (2013). Isolation of active components derived from rhizome of Euphorbia wallichii Hook. International Journal of Ayurvedic $\quad$ and Herbal Medicine, 3(3), 1173-1183.

[9] Patra JK, Gouda S, Sahoo SK and Thatoi HN. (2012). Chromatography separation, $1 \mathrm{H}$ NMR analysis and bioautography screening of methanol extract of Excoecaria agallocha L. from Bhitarkanika, Orissa, India. Asian Pacific Journal of Tropical Biomedicine, 2(1), S50-S56.

[10] Isaac JU, Fasihuddin BA and Hauwa AU. (2019). Extraction, Elucidation, Characterization and Evaluation of Antibacterial Activity of Four Pure Compound from Barringtonia racemosa Leaf Extract. World Journal of Pharmacy and Pharmaceutical Sciences, 8(8), 184-223.

[11] Umaru IJ, Badruddin BA and Umaru HA. (2019). Extraction, Isolation and Characterization of New Compound and Anti-Bacterial Potentials of the Chemical Constituents Compound from Leptadenia Hastata Leaf Extract. ChemRxiv, 1-42.

[12] Kalaiselvan A, Gokulakrishnan K and Anand T. (2012). Gas chromatography mass bioactive components of the ethanol extract of Andrographis paniculata. Journal Biomedical Science, 20(15), 1-3.

[13] Shalini S and Sampathkumar P. (2012). Phytochemical screening and antimicrobial activity of plant extracts. International Journal of Current Science, 20, 209-218.

[14] Janice GS. (2008). Key concepts - Mass spectrometry, infrared spectroscopy and nuclear magnetic resonance spectroscopy.Organic Chemistry 2nd Edition. New York, McGraw-Hill, 485-525.

[15] Efdi M, Fujita S, Inuzuka T and Koketsu M. (2010). Chemical studies on Goniothalamus tapis Miq. Natural Product Research, 24(7), 657-662.

[16] Boyan B, James H and Judicael P. (2005). Principles of accessing bacterial susceptibility to antibiotics using agar diffusion method, Journal of Antimicrobial Chemotherapy, 61, 1295-1301.

[17] Prashanth VK, Chauhan NS, Padh H and Rajani M. (2006). Search for antibacterial and antifungal agents from selected Indian medicinal plants. Journal of Ethnopharmacology, 107(2), 182-188.

[18] McLaughlin JL, Rogers LL and Anderson JE. (1991). The use of biological assays to evaluate botanicals. Drug Information Journal, 32(2), 513-524.

[19] Wang HX, Liu CM, Liu Q and Gao K. (2008). Three types of sesquiterpenes from rhizomes of Atractylodes lancea. Phytochemistry, 69(10), 2088-2094.

[20] Tailor CS and Goyal A. (2014). Antioxidant activity by DPPH radical scavenging method of Ageratum conyzoides Linn. leaves. American Journal of Ethnomedicine, 1(4), 244-249.

[21] Duc LV, Thanh TB and Hau TN. (2018). Flavonoids from Dicliptera chinensis (L) Nees Grown in Vietnam and their Anti-Inflammatory Activities. Asian Journal of Biomedical and Pharmaceutical Sciences, 8(64), 6-13.

[22] Bei D and An G. (2016). Pharmacokinetics and tissue distribution of 5, 7-dimethoxyflavone in mice following single dose oral administration. Journal of Pharmaceutical and Biomedical Analysis, 119, 65-70. 
[23] Silverstein RM, Webster FX and Kiemle DJ. (2005). Spectrometric Identification of Organic Compound.ISBN 9780-471-39362-7.

[24] Zhu CL. (2014). Chemical constituents of $\mathrm{n}$-BuOH extract from Phyllanthus matsumurae. Zhong yao cai= Zhongyaocai. Journal of Chinese Medicinal Materials, 37(4), 608-610.

[25] Niknamian S and Niknamian S. (2016). Dodecanoic-Acid in Extra Virgin Coconut Oil, May Reduce the Incidence of Heart Disease and Cancer in Humans. International Journal of Science and Research, 5(1), 792-797.

[26] Rayan P1 and McDonnell PA. (2014). Dietary Supplementation of Dodecanoic Acid in Maternal Mice Enhances Resistance to Giardia duodenalis Infection in Suckling Neonatal Pups. Pharmacognosy Communications, 4(4), 8389.

[27] Yamashita S, Igarashi M, Hayashi C, Shitara T, Nomoto A, Mizote T and Shibasaki M. (2015). Identification of selfgrowth-inhibiting compounds lauric acid and7-(Z)-tetradecenoic acid from Helicobacter pylori. Microbiology, 161, 1231-1239.

[28] Umaru IJ, Badruddin FA and Umaru HA. (2018).Cytotoxicity Brine Shrimp Activity of Leptadenia hastata (Per) Decne Leaves, Stem-bark and Roots Extract. International Journal of Biochemistry and Physiology, 3(2), 01-09.

[29] Isaac JU, Fasihuddin AB, Zaini BA and Hauwa AU. (2018). Cytotoxicity (Brine shrimp Lethality Bioassay) of Barringtonia racemosa Leaves, Stem-Bark and Root Extract. Journal of Biotechnology and Bioengineering, 2(2), 1-6.

[30] Anderson KM, Odell PM, Wilson PW and Kannel WB. (1991).Cardiovascular disease risk profiles. American Heart Journal, 121(1), 293-298.

[31] Aqil F Ahmad I and Mehmood Z. (2006). Antioxidant and free radical scavenging properties of twelve traditionally used Indian medicinal plants. Turkish Journal of Biology, 30(3), 177-183.

[32] Isaac JU and Fasihuddin AB. (2018). Antioxidant and Biological Activities of Leptadenia Hastata ethyl acetate Roots Extracts, Medicinal \& Analytical Chemistry International Journal, 2(1), 1-5.

[33] Velioglu YS, Mazza G, Gao L and Oomah BD. (1998).Antioxidant activity and total phenolics in selected fruits, vegetables, and grain products. Journal of Agricultural and Food Chemistry, 46(10), 4113-4117.

[34] Pourmorad F, Hosseinimehr SJ and Shahabimajd N. (2006). Antioxidant activity phenol and flavonoid contents of some selected Iranian medicinal plants. African Journal of Biotechnology, 5(11), 1142 - 1145.

[35] Asok Kumar K, Uma Maheswari M, Sivashanmugam AT, Subhadra Devi V, Subhashini N and Ravi TK. (2009). Free radical scavenging and antioxidant activities of Glinus oppositifolius (carpet weed) using different in-vitro assay systems. Pharmaceutical Biology, 47(6), 474-482.

[36] Mariya S and Reena L. (2017). Evaluation of pigments as antioxidant and antibacterial agents from Beta vulgaris Linn. International Journal of Current Pharmaceutical Research, 9, 33-37.

[37] Daljit SA and Jasleen, K. (1999). Antimicrobial activities of spices. International Journal of Antimicrobial Agents $12,257-262$.

[38] Prakash V, Kishor MP and Meenakshi M. (2009). Screening of medicinal plant extracts for antioxidant activity. Journal of Medicinal Plants Research, 3(8), 608-612.

[39] Apu AS, Muhit MA, Tareq SM, Pathan AH, Jamaluddin ATM and Ahmed M. (2010). Antimicrobial activity and brine shrimp lethality bioassay of the leaves extract of Dillenia indica Linn. Journal of Young Pharmacists, 2(1), 50-53.

[40] Nayan BR, Nariya PB and Shukla VJ. (2011). Antibacterial and antifungal activity from flower extracts of Cassia fistula L.: An ethnomedicinal plant. International Journal of PharmTech Research, 3(1), 160-168.

[41] Jan Hudzicki (2016). Kirby-Bauer Disk Diffusion Susceptibility Test Protocol. American Society of Microbiology, 1-23.

\section{How to cite this article}

Umaru IJ, Umaru HA, Yakubu O and Umaru KI. (2020). Isolation and characterization of chemical constituents, cytotoxicity, antibacterial and antioxidant activity of the isolates, crude extract from Hornstedtia scyphifera var Leaf. GSC Biological and Pharmaceutical Sciences, 10(2), 70-98. 